FIU Law Review

Winter 2007

\title{
Evaluating Florida's Capital Sentencing Scheme Through the Aggregate Protection and Safeguards Found in the Sixth, Eighth and Fourteenth Amendments of the United States Constitution
}

Luis M. Fusté

Follow this and additional works at: https://ecollections.law.fiu.edu/lawreview

Part of the Other Law Commons

Online ISSN: 2643-7759

Recommended Citation

Luis M. Fusté, Evaluating Florida's Capital Sentencing Scheme Through the Aggregate Protection and Safeguards Found in the Sixth, Eighth and Fourteenth Amendments of the United States Constitution, 2 FIU L. Rev. 97 (2007).

DOI: https://dx.doi.org/10.25148/lawrev.2.1.12

This Comment is brought to you for free and open access by eCollections. It has been accepted for inclusion in FIU Law Review by an authorized editor of eCollections. For more information, please contact lisdavis@fiu.edu. 


\section{Comments}

\section{Evaluating Florida's Capital Sentencing Scheme Through the Aggregate Protection and Safeguards Found in the Sixth, Eighth and Fourteenth Amendments of the United States Constitution}

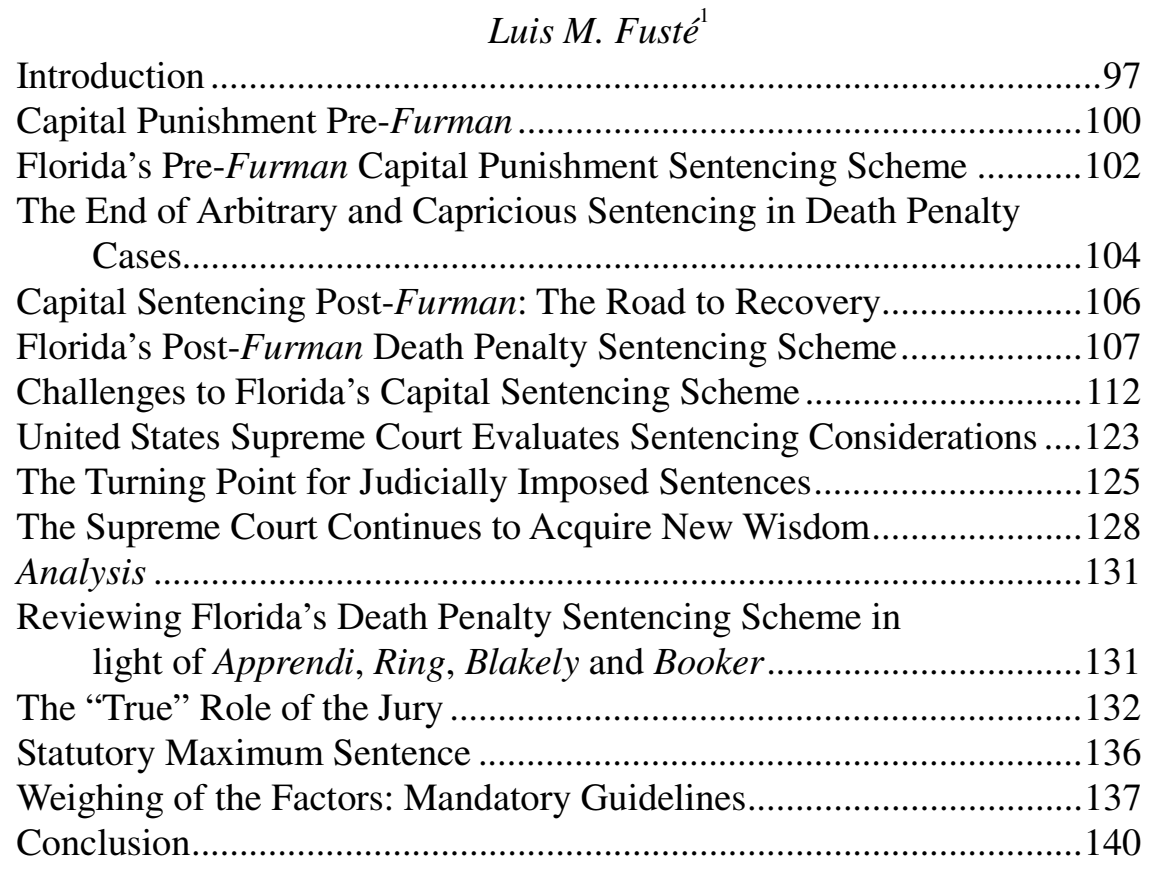

\section{INTRODUCTION}

The concept of capital punishment and its origin may be difficult to identify; however, societies throughout time have implemented it as a form of punishment. ${ }^{2}$ Originally recognized as a private vengeance, ${ }^{3}$ the State, through its sovereign authority, accepted the power to punish those who

\footnotetext{
1 Luis M. Fusté is a J.D. graduate from Florida International University College of Law, May 2006, and has worked in law enforcement for over 23 years.

2 Furman v. Georgia, 408 U.S. 238, 334-35 (1972) (Marshall, J., concurring).

$3 \quad$ Id. at 333.
} 
violated its laws. ${ }^{4}$ The history of capital punishment under common law commenced in England as early as the Thirteenth Century. ${ }^{5}$ While early English law recognized eight major capital crimes, ${ }^{6}$ capital punishment's reach escalated to well over 200 numbered offenses. ${ }^{7}$ Although capital punishment was less common in the colonies, American colonies codified capital offenses early in 1636 when the Massachusetts Bay Colony enumerated 13 acts as punishable by death. ${ }^{8}$

In America, opposition to the death penalty came early in its brief capital punishment jurisprudence. ${ }^{9}$ In 1794, Pennsylvania abolished capital punishment for all crimes except murder in the first degree, which was held to encompass all willful, deliberate and premeditated killings. ${ }^{10}$ This change prescribed mandatory death penalty for all those convicted of murder. ${ }^{11}$ Following Pennsylvania's reform, Virginia and several other states enacted similar statutes. ${ }^{12}$ This anti-capital punishment movement traveled across the country, yet it lost its momentum with the commencement of the Civil War. ${ }^{13}$ Movements aimed at ending or reforming the use of the death penalty have accompanied capital punishment since it was imported from Europe. ${ }^{14}$

To this day, the United States continues to struggle, not only with the imposition of the death penalty, but with the method of execution. ${ }^{15}$ According to a Gallup Poll survey, two in three Americans say they are in favor of the death penalty for convicted murderers; ${ }^{16}$ however, when asked to

4 Id. n.41 (noting that the Code of Hammurabi is one of the first known laws to recognize death as a form of punishment for homicide).

5 McGautha v. California, 402 U.S. 183, 197 (1971).

6 Furman, 408 U.S at 334 (recognizing treason, petty treason (killing of husband by his wife), murder, larceny, robbery, burglary, rape, and arson as capital crimes).

$7 \quad I d$.

$8 I d$. at 335 (using the Old Testament as the source, the crimes punishable by death were: idolatry, witchcraft, blasphemy, murder, assault in sudden anger, sodomy, buggery, adultery, statutory rape, rape, manstealing, perjury in a capital trial, and rebellion).

9 McGautha, 402 U.S. at 198; see also Jill M. Cochran, Note, Courting Death: 30 Years Since Furman, is the Death Penalty Any Less Discriminatory? Looking at the Problem of Jury Discretion in Capital Sentencing, 38 VAL. U. L. REV 1399, 1405 n.34 (2004) (noting that the Colonists were less eager to apply the death penalty when compared to the British).

10 Furman, 408 U.S. at 336; McGaurtha, 402 U.S. at 198.

11 Furman, 408 U.S. at 336.

12 McGautha, 402 U.S. at 198.

13 Cochran, supra note 7, at 36 (noting that as a capital abolishment movement was sweeping the country, Maine enacted a statute that stayed all executions for one year after convictions. This movement ended when the Civil War caused a shift to the nation's focus. The movement emerged once again after the war; however, penal reform, the Great Depression as well as World War I and II placed a permanent halt in the efforts to abolish the death penalty).

14 Furman, 408 U.S at 342.

15 Id.

16 Lydia Saad, Support for Death Penalty Steady at 64\%, Slightly Lower than in Recent Past, THE GALLUP ORGANIZATION, December 8, 2005, http://poll.gallup.com/content/default.aspx?ci=20350\&pg $=1$ (last visited May 9, 2006). 
choose between life imprisonment and death, the numbers are quite lower. ${ }^{17}$ Currently, 38 states still have death penalty statutes. ${ }^{18}$ Internationally, however, there are more nations that have abolished capital punishment than those who continue to impose it. ${ }^{19}$

While a general opposition to the death penalty continues in this country, ${ }^{20}$ today the greater concern turns on who is to determine whether a person is sentenced to death: the judge or the jury? ${ }^{21}$ Modern capital punishment jurisprudence starts with the Supreme Court's decision in Furman v. Georgia. ${ }^{22}$ The impact Furman had on this nation's utilization of capital punishment can only be rivaled by a string of recent Supreme Court decisions which, when examined collectively, reveal a new turning point in the Court's evolving capital punishment jurisprudence. ${ }^{23}$

Through an analysis of various decisions, this Comment will trace the United States Supreme Court's jurisprudence on the issue of capital punishment and how these decisions have varied in light of the challenges asserted by those seeking relief. Additionally, by examining these cases with a focus on Florida's capital punishment jurisprudence, this Comment will illustrate how the development of capital punishment jurisprudence and Sixth Amendment protection by the courts has rendered Florida's current

17 Id.

18 Amnesty International, Facts and Figures on the Death Penalty, http://web.amnesty.org /pages/deathpenalty-facts-eng (last visited August 24, 2006).

19 Id. (88 countries have abolished Capital Punishment while 69 continue to exercise death penalty statutes. In the U.S. 60 prisoners were executed in 2005, bringing the year-end total to 1004 executed since the use of the death penalty was resumed in 1977. As of January 1, 2006, over 3,400 prisoners are under a sentence of death. The death penalty is also provided under U.S. federal military and civilian law).

20 See Bruce Fein, Death Penalty Usurpations, WASH. TIMES, Feb.10, 2004, available at http://www.washingtontimes.com/commentary/20040209-090307-1481r.htm (last visited Jan. 16, 2007). The following are several of the organizations who oppose the death penalty and were consulted during Simmons v. Roper, 112 S.W. 3d 397 (Miss 2003), whereby the Missouri Supreme Court held that executing individuals under 18 years of age at the time of their capital crimes was prohibited by the Eighth Amendment: American Psychiatric Association, the American Academy of Child and Adolescent Psychiatry, American Friends Service Committee, Mormons for Equality and Social Justice, The Rabbinical Assembly and the United States Catholic Conference.

21 Benjamin F. Diamond, The Sixth Amendment: Where Did the Jury Go? Florida's Flawed Sentencing in Death Penalty Cases, 55 FLA. L. REV. 905, 906 (2003) (this comment complements Diamond's article by adding the more recent United States Supreme Court decisions which reveal the Court's undertaking in expanding Sixth Amendment protection).

22 Furman v. Georgia, 408 U.S. 238 at 291, (holding that the death penalty as applied by the states was arbitrary and capricious; states must adopt statutes that provide "guided discretion").

23 See Apprendi v. New Jersey, 530 U.S. 466 (2000) (holding that other than the fact of a prior conviction, any fact that increases the penalty for a crime beyond the prescribed statutory maximum must be submitted to a jury, and proved beyond a reasonable doubt); Ring v. Arizona, 536 U.S. 584 (2002) (holding that an increase in a defendant's authorized punishment reliant on the finding of a fact, that fact must be found by a jury beyond a reasonable doubt); Blakely v. Washington, 542 U.S. 296 (2004) (defining statutory maximum as "the maximum sentence a judge may impose solely on the basis of the facts reflected in the jury verdict or admitted by the defendant"). 
death penalty statute unconstitutional. The sequence of cases will reveal that whereas Florida's capital punishment sentencing scheme did at one time conform to the Supreme Court's mandate under Furman, today it is unconstitutional.

\section{CAPITAL PUNISHMENT PRE-FURMAN}

Since the Furman decision appears to be the point of demarcation on the new era of change with respect to application of the death penalty, a brief look at capital punishment jurisprudence that preceded Furman is appropriate. Merely six months prior to the decision in Furman, the Supreme Court ruled McGautha v. California. ${ }^{24}$ In McGautha, the Court determined that statutes that permitted a jury to impose the death penalty without governing standards - thereby entrusting the imposition of a death penalty to the jury's absolute discretion-did not infringe upon a defendant's constitutional rights. ${ }^{25}$ Because the petitioners were from different states, the $\mathrm{Su}$ preme Court dealt with statutes from both California and Ohio. ${ }^{26}$

Dennis Councle McGautha, a co-defendant to a robbery-homicide was convicted of murder and sentenced to death under California law. ${ }^{27}$ Prescribed by California statute, punishment for a capital felony was determined in a separate proceeding following the trial on the issue of guilt. ${ }^{28}$

James Edward Crampton was sentenced to death under an Ohio statute after being convicted of murdering his wife. ${ }^{29}$ The applicable Ohio death penalty statute at the time provided that the jury alone would determine guilt and punishment after a single trial and in a single verdict. Furthermore, the trial or the appellate court could not modify the jury's death verdict. ${ }^{30}$

Although the Court was dealing with the statutes of two states, it recognized that the decision would be based on whether the Federal Constitution prohibited the procedures used by each of the states to sentence the

24 McGautha v. California, 402 U.S. 183 (1971).

25 Id. at 183-85.

26 CAl. Penal Code $\$ 190.1$ (1970); OHIO Rev. Code ANN. § 2947.05 (1954).

27 Id. at 185; see also CAL. PENAL CODE $\$ 190.1$ ("The guilt or innocence of every person charged with an offense for which the penalty is in the alternative death or imprisonment for life shall first be determined, without a finding as to penalty. If such person has been found guilty of an offense punishable by life imprisonment or death, and has been found sane on any plea of not guilty by reason of insanity, there shall thereupon be further proceedings on the issue of penalty, and the trier of fact shall fix the penalty.").

28 McGautha, 402 U.S. at 185.

29 Id. at 187.

30 Id. at 182-95. (the jury was instructed as follows: "If you find the defendant guilty of murder in the first degree, the punishment is death, unless you recommend mercy, in which event the punishment is imprisonment in the penitentiary during life") $I d$. at 194. Four hours later, the jury returned a verdict of guilty, with no recommendation for mercy. Id. at 182. See also OHIO REv. CoDE ANN. § 2947.05. (the statute permits the verdict to stand unless there is prejudicial error vitiating the conviction or insufficient evidence to convict penalty). 
defendants to death. ${ }^{31}$ Both defendants had a common claim under the Fourteenth Amendment's guarantee of due process: "[T]hat the absence of standards to guide the jury's discretion on the punishment issue is constitutionally intolerable." ${ }^{, 32}$ The Court conducted an exhaustive inquiry into the history tracing capital punishment back to colonial times and through the modern era. ${ }^{33}$ It recognized that academic and professional sources have recommended that jury sentencing discretion should be guided by standards of some sort, ${ }^{34}$ that several states had enacted new criminal codes adopting features of the Model Penal Code, and that others had adapted laws with respect to murder and the death penalty in other ways. ${ }^{35}$ However, none of the states had adopted statutory criteria for imposition of the death penalty. ${ }^{36}$

In evaluating the States' practices using federal constitutional standards, the Court rejected the due process argument. ${ }^{37}$ The Court reasoned that sole discretion of the jury to determine life or death in capital cases is not offensive to the Constitution and that an established set of standards to guide the jury would be impossible. They noted that, "[t]o identify before the fact those characteristics of criminal homicides and their perpetrators which call for the death penalty and to express these characteristics in language which can be fairly understood and applied by the sentencing authority appear to be tasks which are beyond present human ability." 38 Furthermore, the Court reasoned that although "a link between contemporary community values and the penal system" must be present in sentencing matters, juries are guided by their "innate capacity" and thus better suited to comprehend the values of the community than those which may be developed by legislature. ${ }^{39}$

The Court placed a great deal of faith on jurors and their moral obligation as guidance. However, it recognized that there may be superior means of rendering a fair decision. ${ }^{40}$ The dissent as expressed by Justice Brennan

31 McGautha, 402 U.S at 196.

32 Id.

33 Id. at197-203.

34 Id. at 202 (noting that the American Law Institute had made such a recommendation in 1959 and that as recent as 1970, the National Commission on Reform of Federal Criminal Laws published a Study Draft of a New Federal Criminal Code which called for mandatory procedural provisions for capital sentencing that a jury was required to consider before rendering its decision).

35 Id.

$36 \quad I d$.

37 Id. at 203.

38 Id. at 204; see also Steven Semeraro, Responsibility in Capital Sentencing, 39 SAN DIEGo L. REv. 79, 102-04 (2002) (noting that the Court's decision was not based on analysis or democratic theory, it relied on jurors' sense of responsibility for their task, since jurors faced with rendering such an tremendous decision will act with appropriate moral seriousness and moral rationality).

39 McGautha, 402 U.S at 204.

$40 I d$. at 221 (acknowledging that while the Federal Constitution required solely that trials be fairly conducted and that guaranteed rights of defendants be thoroughly respected, the American Law Institute and the National Commission on Reform of Federal Criminal Laws had concluded that bifur- 
called for the reversal of both death penalties and the imposition of a set of guidelines to aid the decision maker in rendering judgment. ${ }^{41}$

\section{FLORIDA's PRE-FuRMan CAPITAL PUNISHMENT SENTENCING SCHEME}

The governing capital punishment statute in Florida during the preFurman era was similar to that of the Ohio statute previously discussed. ${ }^{42}$ Under Florida law at that time, if an individual was found guilty of an offense punishable by death, the jury's verdict imposed the penalty of death unless a recommendation of mercy was made by a majority vote. ${ }^{43}$ The sentence of death in a capital case was therefore mandatory with exceptions. ${ }^{44}$ In deciding whether to impose a life or death sentence, the sentencing body in Florida was left with no specific standards which it could draw from to guide its decision-making process. ${ }^{45}$ In Florida, the jury had broad parameters in what it could consider when deciding whether the death penalty or life imprisonment was the appropriate sentence. ${ }^{46}$ Furthermore, under the then-existing statute, when the right to a jury trial was waived, or when the defendant pled guilty or nolo contendre, the judge sitting alone made the determination whether to impose the sentence of death or life imprisonment after it found the defendant guilty of a capital offense. ${ }^{47}$

The jury's unfettered discretion in determining whether to impose the death penalty or life imprisonment were challenged under various theories. ${ }^{48}$ One such case was Thomas v. Culver, wherein a black male convicted of raping a white female was sentenced to death under Florida's capital punishment statute of the time. ${ }^{49}$ The defendant argued that Florida's statute gave the jury "uncontrolled and unfettered power to impose the

cated trials and standards for jury sentencing discretion were superior means of dealing with capital cases).

41 Id. at 250, 252 (Brennan, J., dissenting) (describing the statutes before the Court as "stark legislative abdication" since there wasn't "the slightest attempt to bring the power of reason to bear on the considerations relevant to capital sentencing." Supervision of this jury process insures consistency in decisions and in its absence "it can amount to nothing more than government by whim, and a government by whim is the very antithesis of due process.") Id.

42 OHIO REV. CODE ANN. § 2947.05 (death penalty was imposed absent a recommendation for mercy by jury)

43 FLA. STAT. $\$ 921.141$ (1971) (stating in pertinent part: "A defendant found guilty by a jury of an offense punishable by death shall be sentenced to death unless the verdict includes a recommendation to mercy by a majority of the jury. When the verdict includes a recommendation to mercy by a majority of the jury, the court shall sentence the defendant to life imprisonment"); see also King v. Moore, 831 So. 2d. 143, 150 (Fla. 2002)

44 Hargave v. Florida, 366 So. 2d. 1, 7 (Fla. 1979).

45 King, 831 So. $2 \mathrm{~d}$ at 150.

46 See State of Florida ex rel. Thomas v. Culver, 253 F.2d 507 (5th Cir. 1958)

$47 \quad$ Id.

48 Id. (noting that defendant Jimmie Lee Thomas challenged the jury's lack of guidance under the Fourteenth Amendment's Equal Protection Clause).

49 Id. 
death sentence on some and not to impose it on others found guilty of the same crime," and thus was contradictory to the Fourteenth Amendment's Equal Protection Clause of the United States Constitution. ${ }^{50}$

The Court of Appeals rejected his argument and reaffirmed the capital sentencing jurisprudence of that time by asserting that due to the "uncontrolled character of the determinations that are confided to the jury" and the "inviolability" associated with the jury room, the statute, which allows the jury to render all determinations, was not unconstitutional in its application. ${ }^{51}$ The Court of Appeals relied on the Supreme Court's decision in Andres v. United States, where it held that where a statute which provided for a jury to decide whether the accused should or should not be capitally punished, the lower court "sufficiently explained the scope of the jury's discretion in granting mercy" by stating that the discretion was entirely within the discretion of the jury.

These cases illustrate that when determining whether a defendant who had been found guilty of a capital offense was to be sentenced to life in prison or to death, the Constitution did not mandate standards to guide the jury in its determination. Even when issues of disparate treatment, unfair application of death penalty statutes, and due process concerns were raised before the courts, capital punishment jurisprudence preferred "to leave to juries finding defendants guilty of a crime the power to fix punishment within legally prescribed limits." ${ }^{53}$ Despite alternative sentencing schemes which would appear to ensure some level of equality, ${ }^{54}$ the courts continued to assert that "[t]wo-part jury trials . . have never been compelled . . . as a matter of constitutional law, or even as a matter of federal procedure." 55

Yet, the argument that unregulated jury discretion may be problematic was not foreign to the Supreme Court. ${ }^{56}$ In Giaccio v. Pennsylvania, the Supreme Court struck down a Pennsylvania statute that empowered juries, without definite standards to govern their discretion or determination, in assessing costs against acquitted defendants with a threat of imprisonment until the costs were paid. ${ }^{57}$ The Court held that due to the statute's lack of

$50 I d$. at 508 (arguing that based on statistics over a period of 20 years, "Negroes convicted of rape as a class and because of their race, were sentenced to death more often than white persons convicted of the same crime.").

$51 \quad I d$.

52 Andres v. United States, 333 U.S. 740, 744 n.4 (1948).

53 Maxwell v. Bishop, 398 F.2d 138, 151 (8th Cir. 1968) (citing Giaccio v. Pennsylvania, 382 U.S. 399, 405 (1969)).

54 See McGautha, 402 U.S. at 202-03 (discussing sentencing schemes that, while not constitutionally mandated, could be adopted by the states); see also id. at 306 (Brennan, J., dissenting) (indicating that the Due Process Clause authorized the Court to ensure that "no State takes one man's life for reasons that it would not apply to another.").

55 Maxwell, 398 F.2d at 151 (citing Giaccio v. Pennsylvania, 382 U.S. 399 (1969)).

56 Giaccio, 382 U.S. 399.

$57 \quad$ Id. at 401. 
standards, a defendant was unable to protect herself from "arbitrarily and discriminatory imposition[s] . . ." Therefore, it was held that the statute failed to meet the requirements of the Due Process Clause. ${ }^{58}$ In what would later become the general principle of modern-capital punishment jurisprudence, the Court in Giaccio established that a statute that "[is] so vague and standardless . . . and leaves . . . jurors free to decide, without any legally fixed standards, what is prohibited and what is not [violated the] premise that the law must be one that carries an understandable meaning with legal standards that courts must enforce.,"59

\section{THE END OF ARbITRARY AND CAPRICIOUS SENTENCING IN DEATH PENALTY CASES}

On June 29, 1972, by a 5-4 vote, the Supreme Court found that the death penalty, as applied by the statutes under review, was cruel and unusual punishment in violation of the Eighth and Fourteenth Amendments. ${ }^{60}$ Justice Brennan and Justice Marshall concluded that capital punishment per se was unconstitutional, and an insult to human dignity. ${ }^{61}$ Yet Brennan's concurring opinion provides an insight to the Court's evolving standards of capital punishment jurisprudence at that time:

Death is truly an awesome punishment. The calculated killing of a human being by the State involves, by its very nature, a denial of the executed person's humanity. The contrast with the plight of a person punished by imprisonment is evident. An individual in prison does not lose the right to have rights. A prisoner retains, for example, the constitutional rights to the free exercise of religion, to be free of cruel and unusual punishments, and to treatment as a "person" for purposes of due process of law and the equal protection of the laws. A prisoner remains a member of the human family. Moreover, he retains the right of access to the courts. His punishment is not irrevocable. An executed person has indeed "lost the right to have rights . ... 'His execu-

$58 \quad I d$. at $401-02$

59 Id. at 403 (while holding that the lack of standards was violative of the Due Process Clause in this particular instance, the Court was quick to point out two factors: first, the Court reached this decision because the issue did not involve a penal statute and second, this decision should cast no doubt on the constitutionality to leave to juries' findings the power to fix punishments).

$60 \quad$ Furman, 408 U.S. 238.

61 Id. at 297-99 (Brennan, J. concurring) (arguing that the imposition of the death penalty was per se unconstitutional, and distinguishing the death penalty from all other forms of punishment imposed by the states, "[d]eath is today an unusually severe punishment, unusual in its pain, in its finality, and in its enormity); see also id. at 358-59 (Marshall, J. concurring) (arguing that the death penalty was excessive and unnecessary and violated the Eighth Amendment). 
tion is a way of saying, you are not fit for this world, take your chance elsewhere." ",62

The Court in Furman established that the imposition of the death penalty in Georgia and Texas was cruel and unusual punishment in violation of the Eighth and Fourteenth Amendments because the imposition of the death penalty was administered in an "unlimited and unguided manner." ${ }^{\text {63 }}$ The Court, in recognizing that death was a different kind of punishment from any other which may be imposed by the states, and that the states were applying this punishment without guidance, struck down all state capital punishment statutes on the ground that they violated the Eighth Amendment's Cruel and Unusual Punishment Clause. ${ }^{64}$ While the Court declined to find capital punishment itself unconstitutional, ${ }^{65}$ it did rule that the application of capital punishment governed by statutes that afforded a sentencing body discretion as to whether a human life should be taken or spared, "must be suitably directed and limited so as to minimize the risk of wholly arbitrary and capricious" application. ${ }^{66}$ The five Justices that made up the majority had their own rationale as to why the statues under review were unconstitutional. ${ }^{67}$ Conversely, Justices Marshall and Brennan argued that the death penalty was per se unconstitutional. ${ }^{68}$ Justice Douglas was concerned that death penalty statutes that lacked standards by which to guide the jury would result in race and class bias. ${ }^{69}$ Justice Stewart, who was not convinced that racial discrimination had been proven, nevertheless concluded that the legal system which imposes a sentence of death "so wantonly and so freakishly" could not be tolerated under the Eighth and Fourteenth

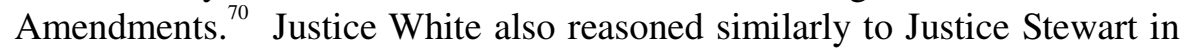
that "the [death] penalty [is] . . . so infrequently imposed that the threat of execution is too attenuated to be of substantial service to criminal justice."

Despite the diverse approaches by the Court in reaching its decision, the result in Furman was a categorical attack on all capital punishment statutes that permitted broad, unguided discretion, and ultimately resulted in an

62 Id. at 290 (Brennan, J. concurring) (citing Stephen, "Capital Punishments," 69 FraSER's MAGAZINE 753, 763 (1864)).

63 Id. at 239-40.

64 Cochran, supra note 54, at 1412 (discussing that the Court's 5-4 decision seemed to signal the demise of the death penalty).

65 Furman, 408 U.S. 238 (Marshall, J. and Brennan, J., concurring).

66 Gregg v. Georgia, 428 U.S. 153, 189 (1976).

67 See supra notes 65-66 (discussing how each justice held the death penalty, as applied by the states, to be unconstitutional).

68 Furman, 408 U.S. 238

69 Id. at 250 (Douglas, J. concurring) ("[t]he death sentence is disproportionately imposed and carried out on the poor, the Negro, and the members of unpopular groups").

70 Id. at 238 (Stewart, J. concurring).

71 Id. at 313 (White, J. concurring). 
end to the imposition of death in an arbitrary and capricious manner. ${ }^{72}$ In light of the Eighth Amendment's Cruel and Unusual Punishment Clause, all capital sentencing statutes had to provide procedural safeguards that guide and restrain the discretion of the sentencing authorities when determining between the death penalty and life imprisonment. ${ }^{74}$ In the years following Furman, thirty-five states rushed to enact new capital sentencing statutes.

\section{CAPITAL SENTENCING POST-FURMAN: THE ROAD TO RECOVERY}

It was not long before newly-amended statutes were challenged before the United States Supreme Court. In 1976, the Supreme Court handed down five decisions regarding capital punishment and the application of newly-enacted death penalty statutes. ${ }^{76}$ Louisiana and North Carolina's statutes were held to be unconstitutional because that they employed mandatory sentencing. ${ }^{77}$ The other three states received the Court's approval. ${ }^{78}$ In Gregg v. Georgia, the Court took note that Georgia had taken steps to cure the infirmities associated with the Furman decision by providing procedural safeguards when seeking the death penalty. ${ }^{79}$ To avoid the application of the death penalty in an arbitrary manner, Georgia's sentencing scheme provided guided discretion and allowed a jury to make the determination as to the presence of aggravating factors. ${ }^{80}$ The jury's findings of

72 Frank Leonard Madia, Death Penalty Jurisprudence: The Difference Between Life and Death, 14 J. SUFFOLK ACAD. L. 73, 82 (2000).

73 U.S. CONST. amend. VIII ("Excessive bail shall not be required, nor excessive fines imposed, nor cruel and unusual punishments inflicted.").

74 Id. at $81-84$.

75 See Gregg, 428 U.S. at 179-80 ("The most marked indication of society's endorsement of the death penalty for murder is the legislative response to Furman. The legislatures of at least 35 States have enacted new statutes that provide for the death penalty for at least some crimes that result in the death of another person. And the Congress of the United States, in 1974, enacted a statute providing the death penalty for aircraft piracy that results in death.").

76 Proffitt v. Florida, 428 U.S. 242 (1976); Gregg, 428 U.S. 153; Jurek v. Texas, 428 U.S. 262 (1976); Woodson v. North Carolina, 428 U.S. 280 (1976); Roberts v. Louisiana, 428 U.S. 325 (1976).

77 Roberts, 428 U.S. 325; Woodson, 428 U.S. at 303 ("A . . constitutional shortcoming of the North Carolina statute is its failure to allow the particularized consideration of relevant aspects of the character and record of each convicted defendant before the imposition upon him of a sentence of death.").

78 Proffitt, 428 U.S. 242; Gregg, 428 U.S. 153; Jurek, 428 U.S. 262.

79 Gregg, 428 U.S. at 162 ("The Georgia statute, as amended after our decision in Furman . . . retains the death penalty for six categories of crime: murder, kidnapping for ransom or where the victim is harmed, armed robbery rape, treason, and aircraft hijacking. . . . The capital defendant's guilt or innocence is determined ... by a trial judge or a jury, in the first stage of a bifurcated trial.").

$80 I d$. at 164-65 ("[T]he judge is also required to consider or to include in his instructions to the jury any mitigating circumstances or aggravating circumstances otherwise authorized by law and any of (10) statutory aggravating circumstances which may be supported by the evidence .... Before a convicted defendant may be sentenced to death . . . the jury, or the trial judge in cases tried without a jury, must find beyond a reasonable doubt one of the 10 aggravating circumstances specified in the statute.”). 
aggravating and mitigating factors were to be taken into consideration before sentencing a person to death. ${ }^{81}$

The Court continued to evolve its application of the Eighth and Fourteenth Amendment when challenges to the constitutionality of various states' death penalty statutes were brought before it. ${ }^{82}$ As the post-Furman era continued, the Court struck down some of the very statutes that it had previously held to be valid. ${ }^{83}$ Previously held to be constitutional, ${ }^{84}$ Georgia's death penalty statute, which required the existence of "aggravating circumstances" before imposing a death penalty, was subsequently struck down for vagueness. ${ }^{85}$

\section{FLORIDA's Post-FuRMan DEATH PENALTy SENTENCING SCHEME}

As a result of Furman, Florida had the nation's first "post-Furman" death penalty statute. ${ }^{86}$ Although different than what the Supreme Court reviewed under Georgia's sentencing scheme in Gregg, ${ }^{87}$ the Court upheld Florida's hybrid system in Proffitt $v$. Florida where a judge and not a jury determined the sentence. ${ }^{88}$ While all procedural designs adopted by the states to impose the death penalty must comport to the Furman mandate, only three states utilize a "hybrid" system: Florida, ${ }^{89}$ Alabama, and Delaware.

81 GA. CODE $\S 17-10-31.1$.

82 Penry v. Lynaugh, 492 U.S. 302 (1989); Godfrey v. Georgia, 446 U.S. 420 (1980); Gregg, 428 U.S. at 173 ("The [Eighth] Amendment must draw its meaning from the evolving standards of decency that mark the progress of a maturing society.").

83 Penry, 492 U.S. at 320. Although in Jurek v. Texas the Court held the Texas statute constitutional. This was due to the fact that it permitted the sentencer to consider relevant mitigating evidence in imposing a sentence. Jurek, 428 U.S. at 271-72. In Penry, the Court found that its application was not in accordance with the Eight and Fourteenth Amendment. Penry, at 302. The defendant argued that "the jury was unable to fully consider and give effect to the mitigating evidence." $I d$. at 303 . "The Texas death penalty statute was applied in an unconstitutional manner by precluding the jury from acting upon the particular mitigating evidence he introduced." Id. at 320.

84 Gregg, 428 U.S. 153.

85 Godfrey, 446 U.S. at 426, 428. ("[I]f a State wishes to authorize capital punishment, it has a constitutional responsibility to tailor and apply its law in a manner that avoids the arbitrary and capricious infliction of the death penalty ... [I]t must channel the sentencer's discretion by "clear and objective standards" that provide "specific and detailed guidance," and that "make rationally reviewable the process for imposing a sentence of death."... [A] death penalty "system could have standards so vague that they would fail adequately to channel the sentencing decision patterns of juries with the result that a pattern of arbitrary and capricious sentencing like that found unconstitutional in Furman could occur.").

86 Dwight Aarons, Getting Out of the Mess: Steps Toward Addressing and Avoiding Inordinate Delay in Capital Cases, 89 J. CRIM. L. \& CRIMINOLOGY 1, 18 (1998).

87 See Gregg, 428 U.S. at 198 (noting that Georgia's new sentencing scheme required that a jury make specific findings of facts as to the presence of aggravating and or mitigating circumstances before the imposition of death).

88 Proffitt, 428 U.S. 242-48 ("The basic difference between the Florida system and the Georgia system is that in Florida the trial judge determines the sentence rather than the jury; the Florida procedures for imposition of the death penalty satisfy the constitutional deficiencies identified in Furman").

89 FLA. STAT. § 921.141(3) (2002). 
Under current Florida law, when a jury finds a defendant guilty of a capital felony, the defendant can be sentenced to death or life imprisonment without parole. ${ }^{92}$ However, to determine whether a sentence of death or life imprisonment will be imposed, the statute directs the court to follow the procedures set forth in Section 921.141(1) of the Florida Statutes. ${ }^{93}$ During this second procedure, the trial judge, along with a jury (preferably the same jury that rendered the guilty verdict) conducts a separate proceeding on the issues of penalty. ${ }^{94}$ The "guided discretion" provided by the statute allows the sentencer to consider specified enumerated aggravating and mitigating factors when deciding between death and a prison sentence."

90 ALA CODE $§ 13$ A-5-46(a) (1994).

91 Del. Code ANN. Ti. 11, § 4209(d) (1995).

92 See FlA. STAT. ANN $§ 775.082$ (West 2004). Penalties:

(1) A person who has been convicted of a capital felony shall be punished by death if the proceeding held to determine sentence according to the procedure set forth in $\S 921.141$ results in findings by the court that such person shall be punished by death, otherwise such person shall be punished by life imprisonment and shall be ineligible for parole.

93 Id.

94 This sentencing phase is mandatory to all death penalty cases since the Court's decision on Furman; see also FLA. STAT. § 921.141 (1) (West 2002) ("If the trial jury is unable to reconvene for a hearing on the issue of penalty, having determined the guilt of the accused, the trail judge may summon a special juror or jurors.").

95 See FlA. STAT. $\$ 921.141$ (5)(6) (West 2002). Aggravating circumstances:

(a) The capital felony was committed by a person previously convicted of a felony and under sentence of imprisonment or placed on community control or on felony probation.

(b) The defendant was previously convicted of another capital felony or of a felony involving the use or threat of violence to the person.

(c) The defendant knowingly created a great risk of death to many persons.

(d) The capital felony was committed while the defendant was engaged, or was an accomplice, in the commission of, or an attempt to commit, or flight after committing or attempting to commit, any: robbery; sexual battery; aggravated child abuse; abuse of an elderly person or disabled adult resulting in great bodily harm, permanent disability, or permanent disfigurement; arson; burglary; kidnapping; aircraft piracy; or unlawful throwing, placing, or discharging of a destructive device or bomb.

(e) The capital felony was committed for the purpose of avoiding or preventing a lawful arrest or effecting an escape from custody.

(f) The capital felony was committed for pecuniary gain.

(g) The capital felony was committed to disrupt or hinder the lawful exercise of any governmental function or the enforcement of laws.

(h) The capital felony was especially heinous, atrocious, or cruel.

(i) The capital felony was a homicide and was committed in a cold, calculated, and premeditated manner without any pretense of moral or legal justification.

(j) The victim of the capital felony was a law enforcement officer engaged in the performance of his or her official duties.

(k) The victim of the capital felony was an elected or appointed public official engaged in the performance of his or her official duties if the motive for the capital felony was related, in whole or in part, to the victim's official capacity. 
Regardless of general admissibility rules under the rules of evidence, the court may allow any evidence as to any matter it deems relevant to the nature of the crime and character of the defendant during this second proceeding. ${ }^{96}$ The state and the defendant may present arguments for or against the sentence of death. ${ }^{97}$ After hearing all of the evidence with regards to aggravating or mitigating factors, the jury renders an advisory sentence. ${ }^{98}$ The jury's advisory sentence, which determines whether the mitigating circumstances are present to offset the aggravating circumstances, is reached by majority decision rather than unanimous vote.

(1) The victim of the capital felony was a person less than 12 years of age.

(m) The victim of the capital felony was particularly vulnerable due to advanced age or disability, or because the defendant stood in a position of familial or custodial authority over the victim.

(n) The capital felony was committed by a criminal street gang member, as defined in s. 874.03.

(6) Mitigating circumstances.--Mitigating circumstances shall be the following:

(a) The defendant has no significant history of prior criminal activity.

(b) The capital felony was committed while the defendant was under the influence of extreme mental or emotional disturbance.

(c) The victim was a participant in the defendant's conduct or consented to the act.

(d) The defendant was an accomplice in the capital felony committed by another person and his or her participation was relatively minor.

(e) The defendant acted under extreme duress or under the substantial domination of another person.

(f) The capacity of the defendant to appreciate the criminality of his or her conduct or to conform his or her conduct to the requirements of law was substantially impaired.

(g) The age of the defendant at the time of the crime.

(h) The existence of any other factors in the defendant's background that would mitigate against imposition of the death penalty.

See also Proffitt, 428 U.S. at 242 ("Florida trial judges are given specific and detailed guidance to assist them in deciding whether to impose a death penalty or imprisonment for life, and their decisions are reviewed to ensure that they comport with other sentences imposed under similar circumstances").

96 See generally Proffitt, 428 U.S. 242. (The court permits all evidence it deems to have probative value. This over inclusive approach does not permit any evidence secured in violation of the Constitution of the United States or Florida.).

97 Id.

98 Fla.Stat. § 921.141 (2) (West 2002). Advisory Sentence By The Jury - After hearing all of the relevant evidence, the jury shall deliberate and render an advisory sentence to the court, based on the following matters:

(a) Whether sufficient aggravating circumstances exist as enumerated in subsection (5);

(b) Whether sufficient mitigating circumstances exist which outweigh the aggravating circumstances found to exist; and

(c) Based on these considerations, whether the defendant should be sentenced to life imprisonment or death.

99 Bottoson v. Moore, 833 So. 2d 693, 710 (Fla. 2002) (Anstead, C.J., concurring) ( "[I]n Florida, the jury's advisory recommendation in a capital case is not statutorily required to be by unanimous vote[, t]he jury's advisory recommendation may be by mere majority vote."). 
Yet, this advisory sentence is not binding on the trial court's decision. ${ }^{100}$ The final determination as to whether the defendant is sentenced to death rests exclusively with the judge. ${ }^{101}$ However, while the jury's sentence is only advisory in character, the court must give deference to the jury's sentence when it weighs all of the possible factors and renders its own decision. ${ }^{102}$ Anytime the court imposes the death penalty, the court must support its verdict by specific findings of fact. ${ }^{103}$ Even though the jury's recommendation is not binding on the court as a matter of law, ${ }^{104}$ the Florida Supreme Court has recognized the important role the jury plays in Florida's capital sentencing scheme and has at times referred to the jury as the "cosentencer." 105 Nevertheless, in the final analysis, it is the court and not the jury who determines the proper sentence to be administered. ${ }^{106}$ The court's power to determine the sentence remains intact even when it goes against the jury's recommendation. ${ }^{107}$ Hence, despite a majority vote by the jury recommending a life sentence, the court may impose a sentence of death. $^{108}$

On the other hand, this power to override is not absolute. Florida $\mathrm{Su}-$ preme Court case law has limited a court's statutory authority to override a jury's advisory sentence to situations "in which the facts suggesting a sentence of death are so clear and convincing that virtually no reasonable person could differ." 109 In Spaziano, the United States Supreme Court held that the application of the Florida standards allowing a trial court to override a

100 FLA. STAT. § 921.141 (West 2002).

101 Fla. STAT. § 921.141 (3) (findings In Support of Sentence of Death-"Notwithstanding the recommendation of a majority of the jury, the court . . . shall enter a sentence of life imprisonment or death ....").

102 Lambrix v. Singletary, 520 U.S. 518, 518 (1997) (noting that "sentencing judge in a "weighing" State (i.e., a state such as Florida that requires specified aggravating circumstances to be weighed against any mitigating circumstances at a capital trial's sentencing phase) is required to give deference to a jury's advisory sentencing recommendation.").

103 FLA. STAT. \$ 921.141(3)(a)(b) (West 2004).

104 Spaziano v. Florida, 468 U.S. 447 (1984) (holding that under Florida's sentencing scheme the jury's recommendation is not binding of the court).

105 Bottoson, 833 So. 2d at 702; see also Espinosa v. Florida, 505 U.S. 1079, 1081 (1992) (Finding that Florida had essentially split the weighing process in two. The jury would weigh the aggravating and mitigating circumstances, and the result of that is then in turn weighed by the court's process of weighing aggravating and mitigating circumstances.).

106 FLA. STAT. \$ 921.141(3).

107 Id.

108 FLA. STAT. \$ 921.141(3)(a)(b). See also Spaziano, 468 U.S. at 463 ("[The] death penalty is not frustrated by, or inconsistent with, a scheme in which the imposition of the penalty in individual cases is determined by a judge ... We see nothing that suggests that the application of the jury-override procedure has resulted in arbitrary or discriminatory application of the death penalty . . . [r] egardless of the jury's recommendation, the trial judge is required to conduct an independent review of the evidence and to make his own findings regarding aggravating and mitigating circumstances.").

109 Bryan A. Stevenson, The Ultimate Authority on the Ultimate Punishment: The Requisite Role of the Jury in Capital Sentencing, 54 ALA L. REV. 1091, 1096 (2003). 
jury's recommendation of a life sentence by a majority vote did not violate the United States Constitution and had not resulted in arbitrary or discriminatory application of the death penalty. ${ }^{110}$

Furthermore, the United States Supreme Court has held that it is not constitutionally necessary for a jury to decide the appropriate sentence to be imposed. ${ }^{111}$ Another safeguard found within the statute is that all sentences of death are automatically subject to review by the Supreme Court of Florida within two years. ${ }^{112}$ These standards provided by the legislature, which regulate the sentencing proceedings, assure that the death penalty will not be imposed in an arbitrary or capricious manner. ${ }^{13}$

The Supreme Court of Florida continues to assert that defendants are adequately protected by way of the statute through its procedural safeguards and post conviction reviews. ${ }^{114}$ The United States Supreme Court, which has analyzed the Florida statute's operation in detail several times, continues to uphold Florida's capital sentencing scheme as constitutional. ${ }^{115}$

With the appearance of "post-Furman" capital punishment statutes comparable to Florida, ${ }^{116}$ and with the Court's refusal to find these unconsti-

110 Spaziano v. Florida, 468 U.S. 447, 448 (1984); See also Thomas v. State, 456 So. 2d 454, 459 (Fla. 1984) (holding that if the facts supporting the sentence of death are clear and convincing, "the ultimate decision as to whether the death penalty should be imposed rests with the trial judge despite a jury's recommendation of life." (citing Hoy v. State, 353 So.2d 826, 832 (Fla. 1977))).

111 Proffitt, 428 U.S. at 251. ("On their face these procedures, like those used in Georgia, appear to meet the constitutional deficiencies identified in Furman. The sentencing authority in Florida, the trial judge, is directed to weigh eight aggravating factors against seven mitigating factors to determine whether the death penalty shall be imposed. This determination requires the trial judge to focus on the circumstances of the crime and the character of the individual defendant.").

112 See Fla. CONST. art. V, Sec 3(b)(1) (stating in pertinent part "the Supreme Court ... Shall hear appeals from final judgments of trial courts imposing the death penalty."); FLA. STAT. § 921.141 (4) (West 2002).

113 Proffitt, 428 U.S. 242.

114 Bottoson, 833 So. $2 \mathrm{~d}$ at 698. (Wells, J., concurring) (noting that in spite of shifting constitutional analysis over the years, Florida's statute provides "effective post-conviction review of the reliability of a defendant's trial and sentencing proceedings"); $I d$. at 720 (Pariente, J. concurring in result only) ("Florida's . . . capital sentencing scheme . . . [provides] a defendant convicted of first-degree murder "with five steps between conviction and imposition of the death penalty". . . The five steps . . are (1) a post-conviction hearing before a jury, (2) a jury recommendation, (3) determination of the sentence by the judge, (4) written findings in support of a death sentence, and (5) review by this Court.")(internal citations omitted).

115 See Proffitt, 428 U.S. 242; Lambrix v. Singletary, 520 U.S. 518, 526 (1997) (noting that "Florida employs a three-stage sentencing procedure. First, the jury weighs statutorily specified aggravating circumstances against any mitigating circumstances, and renders an "advisory sentence" of either life imprisonment or death . . . . Second, the trial court weighs the aggravating and mitigating circumstances, and enters a sentence of life imprisonment or death; if the latter, its findings must be set forth in writing. The jury's advisory sentence is entitled to "great weight" in the trial court's determination ..., but the court has an independent obligation to determine the appropriate punishment. . . Third, the Florida Supreme Court automatically reviews all cases in which the defendant is sentenced to death.").

116 E.g. 42 PA. CONS. STAT. § 9711(e)(8) (1988); see also Blystone v. Pennsylvania, 494 U.S. 299, 303 (1990) (upholding the Pennsylvania statute in holding that the statute had, "cured the constitutional defect identified in Furman."). 
tutional, it appeared as though the states had taken the Court's direction in Furman when drafting capital sentencing schemes that comported with the Eighth Amendment. ${ }^{17}$ State legislatures have continued to draft statutes that comply with the directive provided by the United States Supreme Court's holding in Furman, ${ }^{118}$ and for the past 28 years, the United States Supreme Court has held Florida's structured "hybrid" sentencing system constitutional and in compliance with Furman. ${ }^{119}$ While Florida's sentencing statute has enjoyed the Court's stamp of approval under various challenges, recent Florida Supreme Court decisions indicate the statute's capital sentencing procedure may very well be unconstitutional. ${ }^{120}$

\section{CHALLENGES TO FLORIDA's CAPITAL SENTENCING SCHEME}

The United States did not execute anyone for four years following the Furman decision. ${ }^{121}$ The decision in that case caused thirty-five states to enact new statutes that would limit the sentencer's discrimination and arbitrariness when deciding to impose a sentence of death. ${ }^{122}$ Four years after Furman, Florida's newly drafted statute was challenged in Proffitt.

In Proffitt, the petitioner stood trial and was found guilty of firstdegree murder. ${ }^{124}$ During Florida's newly created separate sentencing hearing, the jury returned an advisory verdict recommending the sentence of death. ${ }^{125}$ Based on the jury's recommendation and the court's own findings, the petitioner was so sentenced. ${ }^{126}$ The petitioner argued that the imposition of the death penalty under any circumstances was cruel and unusual punishment in violation of the Eighth and Fourteenth Amendments. ${ }^{127}$

At the time Proffitt came before the Court, the central concerns as to the death penalty's constitutionality were those issues addressed in (1976).

117 Proffitt, 428 U.S. 242; Gregg v. Georgia, 428 U.S. 153 (1976); Jurek v. Texas, 428 U.S. 262

118408 U.S. at 313 ("A capital sentencing scheme must, in short, provide a "meaningful basis for distinguishing the few cases in which [the penalty] is imposed from the many cases in which it is not.").

119 See Proffitt, 428 U.S. 242; Dobbert v. Florida, 432 U.S. 282 (1977); Spaziano, 468 U.S. 447; Hildwin v. Florida, 490 U.S. 638 (1989) (per curiam); Lambrix, 520 U.S. 518.

120 King v. Moore, 831 So. 2d 143 (2002); Bottoson, 833 So. 2d 693, 724 (Lewis, J., concurring in result only).

121 Cochran, supra note 9, at 1416

122 Id. at 1417; see also supra note 72.

123 Proffitt, 428 U.S. 242.

124 Id. at 246

125 Id.

126 Id. at 247 (The court's findings supporting the sentence were as follows: as to aggravating circumstances (1) the murder was premeditated and occurred in the course of a felony (burglary); (2) the petitioner has the propensity to commit murder; (3) the murder was especially heinous, atrocious, and cruel; and (4) the petitioner knowingly, through his intentional act, created a great risk of serious bodily harm and death to many persons; no mitigating statutory mitigating circumstances existed).

127 Id. 
Furman. ${ }^{128}$ As long as a state's sentencing scheme "assure[d] consistency, fairness, and prevented the arbitrary and capricious imposition of the death penalty," the state's newly drafted statute would prevail. ${ }^{129}$ The Court held that the death penalty was properly imposed because under Florida's sentencing scheme, the trial judge was required to focus on the circumstances of that particular crime and the character of the individual defendant through the statute's mandatory aggravating and mitigating factors. ${ }^{130}$

The central meaning of the Court's decision was not whether a judge or jury should determine the sentence given, but rather that the Constitution only requires that the sentencing body be provided with a procedure which furnishes guidance in determining the imposition of death. ${ }^{131}$ By assessing early post-Furman decisions under the Eighth Amendment, the key to success for a capital sentencing statute was whether the death penalty was imposed in a capricious and arbitrary manner and thus would be tantamount to cruel and unusual punishment. ${ }^{132}$

One year after Proffitt, the Supreme Court had a second opportunity to review and analyze Florida's capital sentencing statute. ${ }^{133}$ The petitioner in Dobbert argued that the Ex Posto Facto Clause prohibited the application of the new statute, which changed the function of judge and jury in the imposition of death sentences because the crime had predated the statute, and at the time he acted there was no valid death penalty statute in effect in Florida. ${ }^{134}$ After the petitioner was found guilty of first-degree murder, the jury's advisory recommendation was a sentence of life imprisonment. ${ }^{135}$ Notwithstanding the jury's recommendation, the judge sentenced the petitioner to death. ${ }^{136}$

The Court rejected petitioner's argument and held that Florida's statute provided significantly more safeguards to the defendant than did the old statute and that the change in the law was not only procedural but also ameliorative. ${ }^{137}$ Although the Dobbert decision addressed procedural concerns,

128 See Stevenson, supra note 109, at 1097.

129 Proffitt, 428 U.S. at 258.

130 Id. at 247.

131 See Cochran, supra note 9, at 1423.

132 Id; see also Gregg v. Georgia, 428 U.S. 153, 222 (1976) (White, J., concurring) ("The Georgia Legislature has plainly made an effort to guide the jury in the exercise of its discretion, while at the same time permitting the jury to dispense mercy on the basis of factors too intangible to write into a statute, and I cannot accept the naked assertion that the effort is bound to fail.").

133 Dobbert v. Florida, 432 U.S. 282 (1977).

134 Id. at 287.

$135 I d$. at 287, (After weighing the aggravating against the mitigating factors, the jury by a 10-to-2 majority found sufficient mitigating circumstances to outweigh any aggravating circumstances).

${ }^{136} I d$. The trial judge under his authority overruled the jury's recommendation and sentenced petitioner to death. In his written findings of fact, the judge provided detailed circumstances of some of the horrors inflicted upon the victims. Id. at 285, 287.

137 Id. at 294-97. 
the Court made declaration worthy of noting. The Court asserted that with the new Florida statute "[d]eath [was] not automatic . . . as it was under the old procedure." 138 As this Comment will address, this single disinclination is vital. ${ }^{139}$

In Barclay v. Florida, the U.S. Supreme Court responded to challenges arguing that certain factors may not be taken into consideration by the "sentencer" when deciding whether to impose the death penalty. ${ }^{140}$ Elwood Barclay challenged the imposition of the death penalty when one of the "aggravating circumstances" relied upon by the trial judge to support the sentence was not among those established by the Florida death penalty statute. ${ }^{141}$ During the post sentencing hearing, the jury rendered an advisory sentence recommending that Barclay be sentenced to life imprisonment. ${ }^{142}$ The trial judge, overriding the jury's recommendation, concluded that " $[\mathrm{t}]$ here are sufficient and great aggravating circumstances which exist to justify the sentence of death ...."

Barclay argued that the trial judge improperly used his criminal record as an "aggravating circumstance." 144 The Court held that "the trial judge's consideration of Barclay's criminal record as an aggravating circumstance was improper as a matter of state law [because] that record did not fall within the definition of any statutory aggravating circumstance, and Florida law prohibits consideration of nonstatutory aggravating circumstances." However, the Court, citing Proffitt, held that irrespective of the violation of state statute, "it [was] clear that [the plurality in Proffitt] saw no constitutional defect in a sentence based on both statutory and nonstatutory aggravating circumstances." 146

In 1994, the Court again examined Florida's capital punishment sentencing scheme in Spaziano v. Florida. ${ }^{147}$ This time, when confronted with the challenges brought forth by the petitioner under the Sixth, Eighth, and Fourteenth Amendments, the Court conducted a lengthy analysis. ${ }^{148}$ The petitioner argued that the statute, which allows a judge to override a jury's recommendation of life in prison, violated the Eighth Amendment's prohi-

138 Id. at 295

139 Apprendi v. New Jersey, 530 U.S. 466 (2000)

140 Barclay v. Florida, 463 U.S. 939 (1983).

141 Id. at $941-42$.

142 Id. at 944

143 Id. at 945 .

144 Id. at 956

145 Id.

146 Id. at 957. The Court also noted that neither the Eighth Amendment nor Florida law prohibited the admissibility of Barclay's criminal record. Id. at 956.

147 Spaziano v. Florida, 468 U.S. 447 (1984).

148 See Stevenson, supra note 109, at 1099. 
bition against cruel and unusual punishment, because the jury's verdict of life should be final.

Furthermore, the override practice violated the Fifth Amendment's Double Jeopardy Clause applicable to the States through the Fourteenth Amendment. ${ }^{149}$ The petitioner urged that the practice of a judge overriding a jury's recommendation violated the Sixth Amendment and the Due Process Clause of the Fourteenth Amendment. ${ }^{150}$ In framing his Sixth Amendment claim, the petitioner was careful to limit his argument only to when a judge overrode a jury recommendation and not to all capital sentencing schemes that did not require a jury's decision. ${ }^{15}$

The United States Supreme Court rejected all of the challenges. ${ }^{152}$ The Court acknowledged that while

[a] capital sentencing is like a trial in the respects significant to the Double Jeopardy Clause [this] does not mean that it is like a trial in respects significant to the Sixth Amendment's guarantee of a jury trial. ... [T] he sentencer, whether judge or jury, has a constitutional obligation to evaluate the unique circumstances of the individual defendant $\ldots{ }^{153}$

Furthermore, the Court also held that, "[t]he Sixth Amendment . . . has [never] guarantee[d] the ... right to a jury determination [on a capital sentencing proceeding]."

In response to the petitioner's argument that the laws and practice in most of the States recognized that juries and not judges were better equipped to make reliable capital-sentencing decisions, the Court noted that while "a majority of jurisdictions have adopted a different practice [that alone] does not establish that contemporary standards of decency are offended by the jury override."

149 Spaziano, 468 U.S. at 457-58. Petitioner Spaziano was indicted, tried and found guilty of firstdegree murder. The sentencing hearing was before the same jury, a majority of the jury recommended life imprisonment. The trial court concluded that the mitigating circumstances were insufficient to outweigh the aggravating circumstances and imposed a sentence of death. Id. at 450-52.

$150 \mathrm{Id}$. at 458 .

151 Id.

152 Id. at 449.

153 Id. at 459.

154 Id.

155 Id. at 464. In support of his argument, petitioner indicated " 30 out of 37 jurisdictions with a capital sentencing statute give the life-or-death decision to the jury, with only 3 of the remaining 7 allowing a judge to override a jury's recommendation of life." Id. at 463 . The Court responded to petitioner's support by indicating that the "Eighth Amendment is not violated every time a State reaches a conclusion different from a majority of its sisters over how best to administer its criminal laws. Although the judgments of legislatures, juries, and prosecutors weigh heavily in the balance, it is for us ultimately to judge whether the Eighth Amendment" is violated by a challenged practice." Id. (internal citation omitted). 
In addressing Florida's capital sentencing statute, the Supreme Court found the statute's application ensured that penalties were not being imposed in an arbitrary and discriminatory manner since the statute had "struck a reasonable balance between sensitivity to the individual and his circumstances." 156 The Court further noted that "the responsibility on a trial judge to impose the sentence in a capital case is [not] so fundamentally at odds with contemporary standards of fairness and decency that Florida must be required to alter its scheme and give final authority to the jury to make the life-or-death decision." 157

Justice Stevens' dissent in Spaziano called into question Florida's "trifurcated procedure for identifying the persons ... who shall be sentenced to death." 158 The dissent noted that although Florida's sentencing procedure was "adopted by a democratically elected legislature," its validity had been presumed. ${ }^{159}$ However, this presumption may not be conclusive. ${ }^{160}$ Justice Stevens suggested that the jury and not the judge may be better suited to make the determination as to the appropriate level of punishment given that the death penalty is an expression of the community's outrage which is "qualitatively different from any other punishment.","161

At the time Spaziano was before the Court, only 3 of the 37 jurisdictions with capital sentencing schemes allowed a judge to override a jury's recommendation of life. ${ }^{162}$ The Court in Gregg noted that evolving social standards affected juries in their decision to impose the death penalty, ${ }^{163}$ and the dissent in Spaziano recommended that a representative of the community should be given the responsibility for making the life or death determination. ${ }^{164}$ Collectively, the Gregg and Spaziano decisions established that

156 Id.

157 Id. at 465 .

158 Id. at 470 (Stevens, J., dissenting) (questioning who should determine whether an individual is sentenced to death - a judge or jury - was premised on the Eighth's Amendment Cruel and Unusual Punishment Clause). This issue concerning Florida's hybrid sentencing scheme continues today albeit under a Sixth Amendment right. See Bottoson v. Moore, 833 So. 2d 693, 703 (2002) (Anstead, C.J., concurring) (citing Ring v. Arizona, 536 U.S. 584, 589) ("requiring findings of fact by a jury of sentencing factors that may affect the ultimate penalty and sentence [applies] to death penalty cases.").

159 Spaziano, 468 U.S. at 471 (Stevens, J. dissenting).

160 Id. (noting that the Eighth Amendment as envisioned by the Framers acts as safeguard against punishment undertaken by the Government "in a manner inconsistent with a fundamental value", albeit with a legislative majority.).

161 Id. at 469 ((Stevens, J., dissenting) ("[E]very Member of this Court has written . . . endorsing the proposition that because of its severity and irrevocability, the death penalty is ... different ... and hence must be accompanied by unique safeguards to ensure that it is a justified response to a given offense.").

162 Id. at 463 (Petitioner pointed out to the Court that 30 out of 37 jurisdictions with capital sentencing schemes allow a jury to make the life or death determination.).

163 Gregg v. Georgia, 428 U.S. 153, 179-82 (1976).

164 Spaziano, 468 U.S. at 481 (Stevens, J. dissenting). 
while society as a whole concurs with the existence of capital punishment, the structure of how to impose death is open to experimentation. ${ }^{165}$

Complying with the notion that the death penalty is closely related to society's view, Justice Stevens argued for "a more focused inquiry into the Eighth Amendment implications of the decision to put an accused to death, and the jury's relationship to those implications."166 As cases involving sentencing schemes have come before the Court, the struggle with a mechanism in which elements of a crime are decided by a jury and sentencing factors are determined by a judge continue to surface. ${ }^{167}$ Whether sentencing factors are elements which must be decided by a jury and not a judge will be determined by the Court in the future. Justice Stevens' request in Spaziano, calling for a more focused inquiry as to the jury's role in sentencing, will be fulfilled as the Supreme Court's sentencing jurisprudence develops.

Florida's death penalty statute has continued to survive challenges as seen when Paul C. Hildwin, Jr. appealed his conviction for first-degree murder and the death sentence imposed by the trial court. ${ }^{168}$ The Florida Supreme Court upheld the trial court's decision and did not discuss Hildwin's argument that the death penalty statute violated the Sixth Amendment because the jury was not required to provide the judge with specific findings as to the aggravating factors. ${ }^{169}$

After an unsuccessful challenge before the Florida Supreme Court, ${ }^{170}$ Hildwin was granted certiorari; once again, the United States Supreme Court was to evaluate Florida's death penalty statute. However, this time the argument was framed around the Sixth Amendment's right to jury trial rather than an Eighth Amendment claim. ${ }^{171}$

During the trial phase, the defendant was found guilty, and thus a separate sentencing proceeding was held. ${ }^{172}$ During that proceeding, the jury unanimously recommended the imposition of the death penalty and the judge concurred, submitting in writing the findings upon which the sentence of death was based. ${ }^{173}$ Despite the defendant's contention that the Sixth Amendment required the jury and not the judge to submit the findings

165 Id. at 464; Gregg, 468 U.S. at 195.

166 Spaziano, 468 U.S. at 477.

167 Julia Marcelle Foy Hilliker, The Evolving Meaning of the Fifth and Sixth Amendments: Sentencing Effects of Aggravating Factors as Elements of the Crime, 80 NOTRE DAME L. REv. 403, 408 (2004).

168 Hildwin v. State, 531 So. 2d 124 (Fla. 1998) (per curiam).

169 Hildwin, 490 U.S. 638 (although the jury's recommendation was unanimous, Hildwin argued that the statute was unconstitutional because the statute authorizes the judge's, and not the jury's findings of fact to determine the sentence).

170 Hildwin, 531 So. $2 \mathrm{~d} 124$.

171 Hildwin, 490 U.S. 638.

$172 I d$.

173 Id. at 639. 
of fact, ${ }^{174}$ the Court again upheld Florida's sentencing system and held that the Sixth Amendment did not bar a judge from making the ultimate determination. ${ }^{175}$

The Court based its decision in this case on the principles established in Spaziano - a judge's imposition of the death penalty on an individual, notwithstanding the jury's recommendation for life, comported with the Sixth Amendment. ${ }^{176}$ In essence, the right to a jury trial did not attach to a capital sentencing hearing. ${ }^{177}$ The Court went on to establish that the sentencing scheme operated solely to guide the judge in selecting a penalty within a range already established by the legislature; and thus the aggravating factor was not an element of the offense. ${ }^{178}$ Faced with a Sixth Amendment challenge, the Hildwin Court applied Spaziano as well as the rationale of McMillian v. Pennsylvania. ${ }^{179}$ These cases recognized and distinguished a state's legislative power to define the elements of a crime, which are required to be proven beyond a reasonable doubt, from prohibited activity, which exposes a defendant to criminal sanctions and is not an element of the crime. ${ }^{180}$ The Supreme Court would later recognize that Hildwin was "the first case to deal expressly with fact-finding necessary to authorize imposition of the more severe of alternative sentences."

Florida's capital sentencing scheme was not the only judge/jury verdict system to be constitutionally challenged. In Baldwin v. Alabama, the United States Supreme Court held that the Eighth Amendment was not violated when the judge imposed a sentence of death irrespective of the jury's verdict. ${ }^{182}$ The basis of the argument was that the judge relied on a jury's recommendation imposing the death penalty when the jury made the decision under a later repealed statute that provided no guidance and permitted it to return a sentence of death along with its guilty verdict. ${ }^{183}$ Citing Spaziano, the Court held that it was "unwilling to say that there is any one right way for a State to set up its capital-sentencing scheme. ${ }^{184}$

174 Id.

175 Id. at 639-41 (noting that the Florida Supreme Court rejected Hildwin's argument that a jury and not a judge should determine the presence of aggravating and mitigating factors without discussion holding that that claim had no merit and ultimately held that the judge's findings were supported by the evidence).

176 Hildwin, 490 U.S. at 640-41 (citing Spaziano v. Florida, 468 U.S. 447 (1984)).

177 Spaziano, 468 U.S. at 459.

178 Id. at 640 (citing McMillan v. Pennsylvania, 477 U.S. 79 (1986)) (recognizing that the state through its sentencing act which exposed a defendant to an increase in his sentence had not created a separate offense which required a jury finding as guaranteed by the Sixth Amendment, state legislatures had the power to determine the elements of a crime and the corresponding burden of proof).

179 McMillan, 477 U.S. 79, 86-88, 93 (1986).

180 Id.

181 Jones v. United States, 526 U.S. 227, 250 (1999).

182 Baldwin v. Alabama, 472 U.S. 372, 389 (1985).

183 Id. at 373 n. $1,378$.

184 Id. at 389. 
Furthermore, the Alabama Supreme Court agreed that the death sentence was not unconstitutional because "the sentencing procedure was saved by the fact that it was the trial judge who was the true sentencing authority, and he considered aggravating and mitigating circumstances before imposing sentence." 185

Similar to Florida's sentencing scheme where the jury renders a recommendation, Ohio's death penalty statute was upheld by the Sixth Circuit Court of Appeals in Greer v. Mitchell. ${ }^{186}$ The defendant argued that permitting the jury to only recommend a sentence as opposed to imposing a sentence would "minimize the jury's sense of responsibility for determining the appropriateness of death." 187 To marginalize a juror's sense of responsibility the defendant claimed violated the Eighth Amendment as the U.S. Supreme Court had held in Caldwell v. Mississippi. ${ }^{188}$ The Sixth Circuit Court of Appeals distinguished Caldwell by asserting that the jury in Greer was in fact mindful of its role irrespective that the ultimate decision as to whether the defendant was sentenced to life or death is imposed solely by the court. $^{189}$

In keeping with the principal concerns pertaining to pre-Furman imposition of death penalties, the United States Supreme Court continued to hold that a sentencing scheme which provided an advisory recommendation to the judge was valid and that the judge need only consider the jury's recommendation to adequately prevent arbitrary and capricious sentencing. ${ }^{190}$ Under a challenge to Alabama's capital sentencing structure, the Supreme Court in Harris rejected the defendant's arguments that the Eighth Amendment required the judge to give "great weight" to the jury's advisory recommendation sentence. ${ }^{191}$ The Court, by way of the Spaziano precedent, held that although the judge was required to place great weight upon the jury's recommendation: "[T]he Constitution permits the trial judge, acting alone, to impose a capital sentence." 192 Furthermore, the Court re-stated the "hallmark" of the constitutional analysis with regard to the imposition of

$185 I d$. at 379 ("If the jury's 'sentence' were indeed the dispositive sentence, the Alabama scheme would be unconstitutional.").

186 Greer v. Mitchell, 264 F.3d 663 (6th Cir. 2001).

187 Id. at $684,687$.

188 Id. Caldwell v. Mississippi, 472 U.S. 320, 323, 340-41 (1985) (noting that a violation of the Eighth Amendment occurs when the determination of the death penalty rests with a sentencer who has been led to believe that accountability for determining appropriateness of defendant's death rests somewhere else).

189 Greer, 264 F.3d at 684, 687.

190 Harris v. Alabama, 513 U.S. 504, 511 (1995).

191 Id.

192 Id. at 515. The Court noted that ALA. CODE $\S 13$ A-5-47 (e) (1994), capital sentencing scheme was similar to Florida's capital sentencing scheme, FLA. STAT. §. 921.141(3) (1985). However, the two States differed in as much as the Florida Supreme Court has held that the trial judge must give "great weight" to the jury's recommendation. Id. at 508-09. 
death in the hands of the state: the "[statutory] scheme [must] adequately channel[] the sentencer's discretion so as to prevent arbitrary results."

As can be seen by the foregoing cases, Florida's capital sentencing scheme, as well as those similar in procedure, were victorious when challenged before the United States Supreme Court under several constitutional grounds. Under the Supreme Court's capital punishment jurisprudence, a state's "sentencing scheme [must] adequately channel[] the sentencer's discretion so as to prevent arbitrary results." ${ }^{, 194}$ Regardless of this requirement, Florida's Supreme Court case law created the Tedder standard; an extra layer of protection triggered only when the court overrode a jury's advisory sentence. ${ }^{195}$ In essence, the standard requires that "to sustain a sentence of death following a jury recommendation of life, the facts suggesting a sentence of death should be so clear and convincing that virtually no reasonable person could differ." 196

Though the Constitution is not offended by a sentencing scheme that permits the judge to decide the final imposition of a death sentence, ${ }^{197}$ other states have followed Florida's lead and adopted the Tedder standard. ${ }^{198}$ In addition to following Florida's scheme, other states have defended their own states sentencing scheme by asserting Florida's capital sentencing structure and its similarities to theirs. ${ }^{199}$ Arizona successfully utilized Florida's "Supreme Court" approved sentencing scheme in Walton to support its argument; however, as this Comment will later discuss, the decision in Walton would perhaps mark the beginning of a change in how the United States Supreme Court would view sentencing factors versus elements of a crime in light of the Sixth Amendment's right to a jury trial. ${ }^{200}$

193 Id. at 511

194 Id.

195 Tedder v. State, 322 So. 2d 908 (Fla. 1975) (per curiam).

196 Id. at 910.

197 Harris, 513 U.S. at 511; see also Spaziano, 468 U.S. at 464 (holding that no federal constitutional right exist to jury sentencing even for a capital offense).

198 Michael F. McTaggart, Criminal Law: 2003 Delaware Supreme Court Decisions, 7 Del. L. REv 89, 98 (2004), (noting that the Delaware Supreme Court in applying the Tedder standard in Pennell v. State, 604 A.2d 1368 (Del. 1992) had in essence adopted established Florida capital punishment jurisprudence); see also John M. Richardson, Reforming the Jury Override System: Protecting Capital Defendant's Rights by Returning to the System's Original Purpose, 94 J. CRIM. L. \& CRIMINOLOGY 455 (2004) (recognizing the Tedder standard overrides the scheme as it is currently administered in Florida and Alabama, which raises real policy and constitutional concerns).

199 Walton v. Arizona, 497 U.S. 639, 647-48 (1990), overruled by Ring v. Arizona, 536 U.S. 584 (2002).

200 See infra, at page 135, section entitled "The Turning Point for Judicially Imposed Sentences," which points out that while Arizona was successful in its argument before the Supreme Court specifically through the precedent of Hildwin, as well as noting that Florida's and Arizona's sentencing schemes were similar, the Supreme Court would ultimately hold Arizona's sentencing statute unconstitutional in Ring v. Arizona, 536 U.S. 584 (2002). See also Walton, 497 U.S. 639 at 710-11 (Stevens, J. dissenting) (noting that the history of trial by jury in criminal cases as well as English common law, held 
In Walton v. Arizona, the Court held that death penalty aggravating factors were sentencing factors, and not elements of a crime; therefore, a finding of fact, on the aggravating factors did not constitutionally require a jury determination. $^{201}$ Walton was convicted of first-degree murder when the jury determined that Walton had robbed, abducted and shot the victim with a .22 caliber derringer gun once in the back of the head after driving him to the middle of the desert. ${ }^{202}$ At trial, the medical examiner testified that the victim had survived the gunshot, regained consciousness, and ultimately died from dehydration, starvation, and pneumonia approximately a day before his body was found. ${ }^{203}$ Similar to the process in Florida, the trial judge conducted a separate sentencing hearing required by Arizona's sentencing scheme. ${ }^{204}$

Whereas Florida's system calls for a jury to provide an advisory recommendation, Arizona permitted the judge alone to determine the existence or nonexistence of any of the aggravating or mitigating circumstances as proscribed by Arizona State Statute $\S 13-703$, subsections $(F)$ and $(G){ }^{205}$ During the post-trial sentencing process, the court found two aggravating circumstances were present $t^{206}$ and that "no mitigating circumstances sufficiently substantial to call for leniency" were present. ${ }^{207}$ Walton was sentenced to death. ${ }^{208}$

Since the United States Court of Appeals for the Ninth Circuit had found Arizona's death penalty statute to be unconstitutional, ${ }^{209}$ the Supreme Court granted certiorari to resolve the conflict. ${ }^{210}$ Walton's Sixth Amendment argument articulated that a jury, not a judge, had to make all findings of fact effecting the sentencing decision; moreover, Arizona's death penalty

\footnotetext{
that the "[jury]. . . [a]s fact-finder ... had the power to determine not only whether the defendant was guilty of homicide but also the degree of the offense.").

201 Walton, 497 U.S. at $647-48$.

$202 I d$. at 644.

203 Id. at 644-45.

204 See id. at 647-49; ARIZ. REV. STAT. ANN. § 13-703 (1989).

205 ARIZ. REV. STAT. ANN. § 13-703 (1989) (Subsection (F) defines 10 aggravating circumstances that may be considered; subsection $(\mathrm{G})$ defines mitigating circumstances as any factors "which are relevant in determining whether to impose a sentence less than death, including any aspect of the defendant's character, propensities or record and any of the circumstances of the offense, including but not limited to" five specified factors).

206 Walton, 497 U.S. at 646 (The two aggravating factors found were (1) the murder was committed in an especially heinous, cruel or depraved manner, $\S 13-703$ (F)(6), and (2) the murder was committed for pecuniary gain. $\S 13-703(\mathrm{~F})(5))$.

207 See Walton, 497 U.S. at 646.

208 Id. at 655-56.

209 See Adamson v. Ricketts, 865 F.2d 1011, 1023 (1988) (holding that the Arizona statutory scheme for imposing the death penalty erroneously lists elements of the offense as factors to be determined by the sentencing judge, and thus deprives a person of his right to a jury decision on the elements of the crime and is therefore in violation of the Sixth and Fourteenth Amendments).

210 Walton, 497 U.S. at 639.
} 
statute would be constitutional if a judge would impose a sentence based on a jury's decision as to what aggravating and mitigating circumstances are present. ${ }^{211}$ The Supreme Court rejected Walton's argument and held "[a]ny argument that the Constitution requires that a jury impose the sentence of death or make the findings prerequisite to imposition of such a sentence has been soundly rejected by prior decisions of this Court., ${ }^{212}$

Florida's capital punishment scheme played a vital role in the Walton decision as evidenced by the Court's use of the standard established in Proffitt, Spaziano and Hildwin; reaffirming that the Sixth Amendment did not require a jury to identify the aggravating factors that permit the imposition of capital punishment. ${ }^{213}$ When Walton attempted to distinguish Florida's system from that of Arizona's, the Court made a compelling assessment of the two capital sentencing schemes,

... Florida['s] jury recommends a sentence, but it does not make specific factual findings with regard to the existence of mitigating or aggravating circumstances and its recommendation is not binding on the trial judge. A Florida trial court no more has the assistance of a jury's findings of fact with respect to sentencing issues than does a trial judge in Arizona. ${ }^{214}$

The Court kept aggravating factors out of the jury's reach by classifying them as mere standards that guide a judge when choosing between the alternative verdicts of death and life imprisonment and not as elements of an offense that require jury determination beyond a reasonable doubt. ${ }^{215}$

Walton's challenge as to what constituted an element of a crime as opposed to an aggravating factor was the not the first challenge of its kind. ${ }^{216}$ When confronted with this determination the United States Supreme Court deferred to the power of a state's legislature to make the determination. ${ }^{217}$ By relying on McMillan, which did not involve a capital sentencing scheme, the United States Supreme Court addressed a fundamental issue surrounding various challenges to capital punishment sentencing schemes: "there is no Sixth Amendment right to jury sentencing, even where the sentence turns on specific findings of fact.

McMillan established that the state could not only determine what was an element of a crime and its related burden of proof to be found by a jury, but could also establish what constituted a sentencing factor, which placed

$211 I d$.

212 Id.

213 Id. at 647-48 (citing Proffitt, 428 U.S. 242; Spaziano, 468 U.S. 447; Hildwin, 490 U.S. 638).

214 Id. at 648

215 See id. at 649-50.

216 McMillan, 477 U.S. 79 (1986).

217 See Hilliker, supra note 167, at 408.

218 See McMillian, 477 U.S. at 93. 
the decision-making in the hands of the court. ${ }^{219}$ Justice Stevens, dissenting and filing a separate opinion in a 5-4 decision, argued that there should be some constitutional limit that permits a legislative declaration which prescribes conduct and is not an element of a crime. ${ }^{220}$ This, Stevens emphasized, would undermine the significance of the reasonable-doubt standard as well as the Constitution itself. ${ }^{221}$

Throughout his dissenting opinions, Justice Stevens has remained consistent in advocating that constitutional limitations require a jury and not the court to determine the proper sentence when determinations of fact needed to be made. ${ }^{222}$ Justice Stevens was certain that the Sixth Amendment required that a jury must establish the determination of facts before the death penalty may be imposed. ${ }^{223}$ Recent jurisprudence supports Justice Stevens' steadfast position.

\section{UNITED STATES SUPREME COURT EVALUATES SENTENCING CONSIDERATIONS}

One year after holding that sentencing considerations that increase a statutory maximum penalty do not absolutely trigger constitutional considerations, ${ }^{224}$ the Court reversed itself and concluded that facts which trigger an increase in maximum sentences need to be submitted to a jury and proven beyond a reasonable doubt. ${ }^{225}$ In Almendarez-Torres, the defendant illegally re-entered the United States after being convicted of a crime and deported. ${ }^{226}$ Pursuant to a penalty provision, ${ }^{227}$ a court was able to impose a

219 Id.

220 See id. 95-103 (Stevens, J. dissenting) (fearing that the majority's decision could undermine the Constitution, Justice Stevens argued that "conduct which exposes a criminal defendant to greater . . . punishment" requires the Due Process protection; fearing that the majority decisions could undermine the Constitution).

221 Id. at 102.

222 See Spaziano v. Florida, 468 U.S. 447, 467-80 (1984) (Stevens, J., concurring in part and dissenting in part) (calling for heightened procedural safeguards because death penalty is qualitatively different from any other punishment that a representative cross section of the community must be given the responsibility for making that decision); McMillan 477 U.S. at 96 (Stevens, J. dissenting) ("A state legislature may not dispense with the requirement of proof beyond a reasonable doubt for conduct that it targets for severe criminal penalties."); Walton, 497 U.S. at 712 (Stevens, J., dissenting) ("The guarantees of jury trial in the Federal and State Constitutions reflect a profound judgment"); Harris v. Alabama, 513 U.S. 504, 526 (1995) (Stevens, J., dissenting) ("The Court today casts a cloud over the legitimacy of our capital sentencing jurisprudence.”).

223 Id.

224 See Almendarez-Torres v. United States, 523 U.S. 224 (1998).

225 Jones v. United States, 526 U.S. 227, 252 (1999).

226 Almendarez-Torres, 523 U.S. at 226.

2278 U.S.C.A. $\$ 1326$ (b)(2) (authorized a court to impose a maximum prison term of 20 years for "any alien described" in subsection (a), if the initial "deportation was subsequent to a conviction for commission of an aggravated felony.") 
higher sentence when a defendant, with a prior conviction unlawfully reentered the United States after deportation.

In the opinion delivered by Justice Breyer, the Court established that the statute permitting the government to determine the proper sentence was in fact a sentencing provision and not an element of crime. ${ }^{229}$ The Court looked to Congress and the "statute's language, structure, subject matter, context, and history" when determining the difference between an element and a factor. ${ }^{230}$ However, the Court took a completely different approach when deciding Jones $v$. United States. ${ }^{231}$ Although factually different, ${ }^{232}$ Almendarez-Torres and Jones dealt with sentencing factors that were exempt from the requirements of charge and jury verdict. ${ }^{233}$

The petitioner in Jones was convicted of armed car jacking. ${ }^{234}$ Under the federal statute, anyone convicted of car jacking, absent any aggravating factors, could face a maximum prison sentence of fifteen years. ${ }^{235}$ However, if any of the enumerated factors were found to be present, the court could impose a maximum penalty of twenty-five years. ${ }^{236}$ The indictment simply listed the carjacking offense with a maximum exposure of fifteen years in prison. ${ }^{237}$ During the sentencing phase, the government recommended a sentence of twenty-five years because one of the victims had suffered serious bodily injury. ${ }^{238}$ The petitioner argued that the higher penalty sought by the government was "out of bounds," since the issue of fact as to whether the victims had sustained serious bodily injury was an element of the crime and thus needed to be proven before a jury.

The Court, in a 5-4 decision, distinguished their holding in Almendarez-Torres by regarding that prior convictions were the exception to a

228 Almendarez-Torres, 523 U. S. at 227.

229 Id. at 227

$230 I d$. at 228

231 See Jones, 526 U.S. 227.

232 The defendant in Jones was convicted of car-jacking; a violent felony involving the use of a firearm. Id. at 229-31. The defendant in Almendarez-Torres, however, illegally re-entered the United States after being deported, and no violence was implicated. Id. at 227.

233 Id. at 229.

234 Id.

235 Id. at 230 .

236 Id. at 230; 18 U.S.C. $\$ 2119$ (1988 ed., Supp. V) The statute states in relevant part:

Whoever, possessing a firearm as defined in section 921 of this title, takes a motor vehicle that has been transported, shipped, or received in interstate or foreign commerce from the person or presence of another by force and violence or by intimidation, or attempts to do so, shall-(1) be fined under this title or imprisoned not more than 15 years, or both, (2) if serious bodily injury (as defined in section 1365 of this title) results, be fined under this title or imprisoned not more than 25 years, or both, and (3) if death results, be fined under this title or imprisoned for any number of years up to life, or both.

237 Jones, 526 U.S. at 230.

238 Id. at 231.

239 Id. 
rule that "facts establishing higher penalties must be treated procedurally similar to offense elements." 240 The Court, rejecting the statute's form over its substance and treating what appeared to be sentencing factors as elements of a crime, established the "maximum penalty test.",241 To determine whether a fact is a sentencing factor or an element of the crime, the Court looked to whether "the finding of such a fact would increase the maximum penalty available for that crime., ${ }^{242}$

The dissent asserted that this decision would cause a "disruption and uncertainty in the sentencing systems of the States." 443 The dissent questioned the holding in Walton, ${ }^{244}$ by noting that whereas a judge's findings may increase the punishment for murder to death, "it is constitutionally impermissible to allow a judge's finding to increase the maximum punishment for carjacking by 10 years. ${ }^{245}$ The ruling and proposition put forth by the holding in Jones called into question judicially-imposed sentences and transformed the Supreme Court's Sixth Amendment jurisprudence. ${ }^{246}$

\section{THE TURNING POINT FOR JUdICIALLY IMPOSED SENTENCES}

On March 28, 2000, when the Supreme Court heard arguments on Apprendi $v$. New Jersey, the predictions made by the Walton dissenters proved to be accurate. ${ }^{247}$ The petitioner was arrested and charged for firing shots into the home of an African-American family. ${ }^{248}$ While Charles Apprendi was subsequently indicted on numerous charges as well as the unlawful possession of a firearm, the state accepted a plea of guilty on two counts of second-degree possession of a firearm and one count of unlawful possession of a bomb. ${ }^{249}$ The statute for possession of a firearm carried a sentencing range of five to ten years. ${ }^{250}$ However, under a separate New Jersey "hate crime" statute, a judge could impose an extended imprisonment term

\footnotetext{
240 Id. 230-35; see Douglas A. Berman, The Roots and Reality of Blakely, 19 CRIM. JUST. 5, 9

241 See Hilliker, supra note 167, at 410.

242 Id.

243 Jones, at 271 (Kennedy, J.; O'Connor, J.; Rehnquist, J.; Breyer, J. dissenting). The dissent's fear of disruption among sentencing guidelines would eventually come true. See United States v. Booker, 125 S. Ct. 738 (2005), discussed below.

244 Walton, 497 U.S. 639 (holding that the Sixth Amendment does not require a jury to determine the aggravating factors which permit the imposition of capital punishment).

245 Jones, 526 U.S. at 272 (Kennedy, J., dissenting) (reasoning that the Court should have chosen Walton for its new approach).

246 Jason E. Barsanti, Ring v. Arizona: The Sixth and Eighth Amendments Collide: Out of the Wreckage Emerges a Constitutional Safeguard for Capital Defendants, 31 PEPP. L. REV 519, 537 (2004). 247 Apprendi, 530 U.S. 466 (2000).

248 Id. at 469 (although this statement was later retracted, the petitioner had stated that he did not want the family in his neighborhood because of their race).

249 Id. at $469-70$.

250 N.J. StAT. ANN. §§ 2C: 39-4(a) and 43-6(a)(2) (West 1995).
} (2005). 
if evidence demonstrated that a defendant committed a crime with the purpose to "intimidate an individual or group of individuals because of race, color, gender, handicap, religion, sexual orientation or ethnicity." ${ }^{251}$

After accepting the petitioner's plea, the trial judge conducted an evidentiary hearing on the issue of Apprendi's purpose in committing the crime and concluded that "that the crime was motivated by racial bias." Based on the "hate crime" statute that permitted a judicially imposed enhancement, Apprendi was sentenced to a term of twelve years. ${ }^{253}$ Supported on the Fourteenth Amendment's Due Process Clause, Apprendi appealed his sentence arguing that the finding of bias upon which his hate crime sentence was based must be proved to a jury beyond a reasonable doubt. ${ }^{254}$ Had the hate crime enhancement not been triggered, Apprendi would have been exposed to a maximum sentence of five to ten years. ${ }^{255}$ Based on precedents such as McMillan ${ }^{256}$ and Almendarez-Torres, ${ }^{257}$ New Jersey took the position that the enhancement statute was a sentencing factor as opposed to an element of the crime. ${ }^{258}$

However, the United States Supreme Court in an opinion by Justice Stevens, implemented the "maximum penalty test" and rejected the State's argument, holding that "under the Due Process Clause of the Fifth Amendment and the notice and jury trial guarantees of the Sixth Amendment, any fact (other than prior conviction) that increases the maximum penalty for a crime must be charged in an indictment, submitted to a jury, and proven beyond a reasonable doubt." $" 259$ The Court also noted that, as applied to state laws, the Fourteenth Amendment mandated the same response. ${ }^{260}$ In analyzing the issues, the Court relied heavily on the historical foundation and recognition of the guarantee in all criminal prosecutions of the right to a public trial by an impartial jury. ${ }^{261}$ While re-affirming the AlmendarezTorres ruling to permit prior convictions, the Court distinguished McMillan by asserting that the statute in McMillan involved a statute that "only raise[d] the minimum sentence that may be imposed and neither alter[ed]

251 Apprendi, 530 U.S. 469. See also N.J. STAT. ANN. § 2C:44-3(e) (authorizing the trial court to impose an extended sentencing term if the defendant is found to have committed the crime with intent to "intimidate an individual or group of individuals because of race, color, gender, handicap, religion, sexual orientation or ethnicity").

252 Id. at 471.

$253 I d$.

254 Id. at 471 .

255 N.J. STAT. ANN. §§ 2C: 39-4(a) (West 1995).

256 McMillan, 477 U.S. 79

257 Almendarez-Torres, 523 U.S. 224.

258 Apprendi, 530 U.S. at 492.

259 Id. at 476.

$260 \mathrm{Id}$.

261 Id. at 478 . 
the maximum sentence nor create[d] a separate offense calling for a separate penalty." 262

As the dissenters' had predicted in Walton, Justice O'Connor dissented, responding that the decision in Apprendi "[would] surely be remembered as a watershed change in constitutional law." ${ }^{, 263}$ By carving out an exception to capital punishment jurisprudence, the Court was able to distinguish and maintain intact the prior decision in Walton, although the door was now wide open for continued evolution regarding capital punishment and the Sixth Amendment. ${ }^{264}$

Twelve years after its holding in Walton which accepted the Arizona death penalty system, ${ }^{265}$ the Court revisited Arizona's capital punishment statute, and on June 24, 2002, the United States Supreme Court held that the Arizona statute violated the Sixth Amendment's right to a jury trial. ${ }^{266}$ In Ring $v$. Arizona ${ }^{267}$ the petitioner was tried and found guilty of felony murder occurring in the commission of an armed robbery. ${ }^{268}$ Arizona's capital punishment sentencing scheme prescribed that the petitioner could only be sentenced to death if a judge conducting a separate sentencing hearing made further findings. ${ }^{269}$ It was during this separate sentencing hearing that the judge had to determine the presence of statutorily enumerated aggravating circumstances and/or mitigating circumstances. ${ }^{270}$ To impose the death penalty, the court, sitting alone, needed only to find one aggravating circumstance and no mitigating circumstances "sufficiently substantial to call for leniency.",271

As a result of the separate sentencing hearing, the judge sentenced the petitioner to death. ${ }^{272}$ Ring appealed arguing that Arizona's capital sentencing scheme violated the Sixth Amendment's right to a jury trial by allowing a judicially imposed sentence that raises a defendant's maximum penalty. ${ }^{273}$ In applying the "maximum penalty test" as created and later put to use in Apprendi, ${ }^{274}$ the Court concluded that under Arizona law, the "death sentence [could] not [be] legally . . . imposed . . . unless at least one aggravating factor is found to exist beyond a reasonable doubt." ${ }^{275}$ Therefore, the

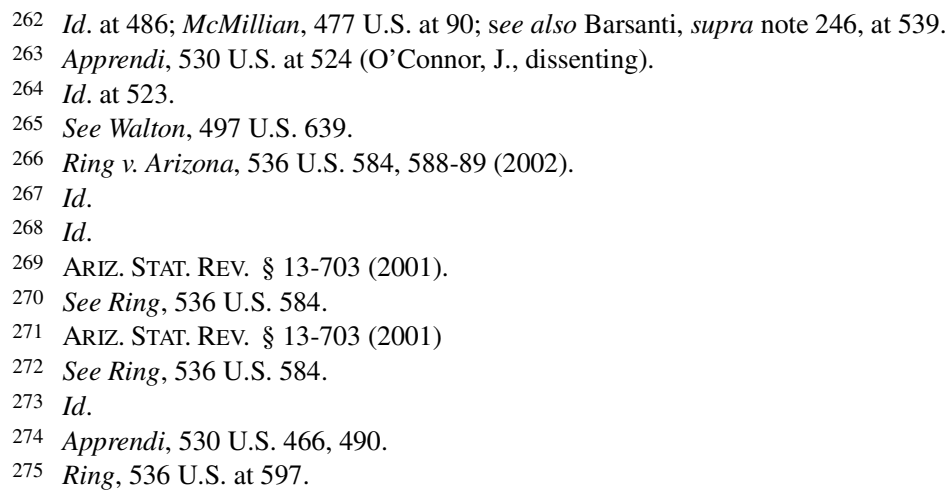


aggravating factor could not be established by the judge under the Sixth Amendment's jury trial guarantee, applicable to the states by the Fourteenth Amendment; it required that a jury determine the aggravating factor. ${ }^{276}$

The State of Arizona argued that the aggravating factors were only sentencing factors, providing a sentencing range between death or life imprisonment and that Ring was sentenced within the range of punishment authorized by the jury verdict. ${ }^{277}$ The Court rejected this argument and pointed out that by cross-referencing the statute to a statutory provision that required a finding of an aggravating circumstance prior to the imposition of death, "Arizona' [s] first-degree murder statute authorizes a maximum penalty of death only in a formal sense."278 Arizona expressed that the judicially determinative factors were designed to overcome "the arbitrary imposition of the death penalty." ${ }^{279}$ The Court countered by declaring that while the pursuit of fairness was admirable, it was not decisive in overriding the jury trial right guaranteed by the Sixth Amendment. ${ }^{280}$

By applying the principles of Apprendi to capital punishment, the Court overruled Walton and continued to expand its statutory analysis with judicially imposed sentencing by maintaining that, "[i]f a State makes an increase in a defendant's authorized punishment contingent on the finding of a fact, that fact-no matter how the State labels it--must be found by a jury beyond a reasonable doubt.,"281 One can truly gauge the Court's developing jurisprudence with regards to sentencing factors and constitutionally protected limitations with a concurring opinion in Ring by Justice Scalia who, in Walton v. Arizona, had upheld the state's sentencing scheme: "[s]ince Walton, I have acquired new wisdom[,] . . to put it more critically, [I] have discarded old ignorance. ${ }^{282}$

\section{The SuPREME COURT CONTINUES TO ACQUIRE NEW WiSDOM}

The Court had an opportunity to expand its previous rulings in $A p$ prendi and Ring when it granted certiorari in Blakely v. Washington. ${ }^{283}$ In Blakely, the petitioner was arrested for abducting his estranged wife by binding her with duct tape and forcing her at knifepoint into a wooden box

276 Id.

277 Id. at 603-04.

278 Ring, 536 U.S. at 585.

279 Ring, 536 U.S. at 607 . Recall that the Furman decision required the states to provide statutory factors, which provide the sentencer guidance in the sentencing process.

$280 \mathrm{Id}$.

281 Id. at 585-86. See also Carol S. Steiker, Things Fall Apart, But the Center Holds: The Supreme Court and The Death Penalty, 77 N.Y.U.. L. REV. 1475, 1485 (2002) (noting that the delay of the Court to apply the Apprendi principle to all capital punishment sentencing schemes put into doubt the supposed Eighth Amendment principle of "heightened reliability" applicable to capital cases).

282 Ring, 536 U.S. at 611 (Scalia, J., concurring).

283 See Blakely, 542 U.S. 296. 
in the bed of his pickup truck. ${ }^{284}$ The petitioner subsequently plead guilty to second-degree kidnapping, a class B felony which, based on the admitted facts of the plea, exposed him to a maximum sentence of 53 months. ${ }^{285}$ However, under Washington law, a judge was permitted to sentence above the standard range if during the sentencing phase, the judge, sitting alone, made a finding of fact as to the presence of statutorily enumerated aggravating factors. ${ }^{286}$ After a three day bench hearing, the judge determined that the petitioner had acted with deliberate cruelty and imposed a 90-month sentence, almost twice the sentence from what the admitted facts of the plea exposed him to. ${ }^{287}$ The petitioner's argued that the sentencing procedure violated his Sixth Amendment right to trial by jury. ${ }^{288}$

The Court was quick to point out that the case required the application of the rule developed in Apprendi: ${ }^{289}$ "[o]ther than the fact of a prior conviction, any fact that increases the penalty for a crime beyond the prescribed statutory maximum must be submitted to a jury, and proved beyond a reasonable doubt." 290 Washington argued that since the applicable statutory maximum for a class B felony was ten years, and not 53 months, Blakely's sentence was not beyond the statutory maximum and therefore Apprendi did not apply. ${ }^{29}$

Justice Scalia, writing for the Court, rejected Washington's statutory maximum argument and clarified that the statutory maximum was, "the maximum sentence a judge may impose solely on the basis of the facts reflected in the jury verdict or admitted by the defendant," for Apprendi purposes. ${ }^{292}$ Relying on constitutional structure and noting that the Framers put a jury-trial guarantee in the Constitution, the majority illustrated that the jury was vested with "rightful control in the judicial department" and that the source of a judge's authority to sentence came from the jury's verdict. ${ }^{293}$ In reversing the Washington Court of Appeals holding, the Court instructed the state to submit its accusations to "the unanimous suffrage of twelve of [Blakeley's] equals and neighbors. ${ }^{294}$

The dissent argued that Washington had implemented a system of guided discretion in order to afford equal protection to combat racial dispar-

284 Id. at 298.

285 Id. at 298-99

286 Id.

287 Id. at 300.

288 Id. at 301.

289 Apprendi, 530 U.S. 466.

290 Blakely, 542 U.S. at 301.

291 Id. at 303; WASH. REV. CODE §§ 9A.20.021(1)(b) (West 2000).

292 Blakely, 542 U.S. at 303.

293 Id. at 306 (noting that without the authority from the jury's verdict, the Framer's intent in the Sixth Amendment would be lost).

294 Id. at 313-14. 
ity because of unstructured review. ${ }^{295}$ Furthermore, the dissent noted that because both criminal history and the character of a defendant were barred from the guilt phase of a criminal proceeding for their prejudicial effects, the State might incur the additional cost associated with a "full-blown jury" in the sentencing phase. ${ }^{296}$ The dissenters argued that the ruling in Blakely would impact the Guidelines because judges were permitted to make determinations of fact that increased sentencing ranges beyond the jury verdict alone, ${ }^{297}$ despite the majority's protestations to the contrary. ${ }^{298}$

Merely six months after its holding in Blakely, ${ }^{299}$ the Court heard arguments on the issue of whether the United States Sentencing Guidelines violated the Sixth Amendment since the guidelines allowed judges to impose enhanced sentences based on determinations of facts, other than prior convictions. ${ }^{300}$ In United States v. Booker, ${ }^{301}$ the petitioner faced a maximum statutory sentence range of 210-to-262 months when his prior conviction was taken into consideration along with the conviction of possessing at least fifty grams of crack cocaine during sentencing. ${ }^{302}$ However, the petitioner was sentenced to 360 months. ${ }^{303}$ This increase in sentencing was possible since the Guidelines authorized departures from the set sentencing range when a judge found aggravating or mitigating circumstances of a kind, or to a degree.

The Court began its analysis by affirming that the applicable sentencing rules were mandatory on all judges. ${ }^{305}$ The Court further clarified that had the rules been merely advisory, a court's ability to select a particular sentence based on circumstances and facts would not implicate the Sixth Amendment. ${ }^{306}$ The Court concluded that there was no difference between the sentence imposed in Blakely and the sentence imposed under the instant case, and thus the Federal Sentencing Guidelines were subject to the jury trial requirements of the Sixth Amendment. ${ }^{307}$ The Court maintained that the principle for their decision was not "the product of recent innovations,"

295 Id. at 318 (O'Connor, J., dissenting).

296 Id. at 319

297 Id. at 325

298 Id. at 305 n.9 ("The Federal Guidelines are not before us, and we express no opinion on them.").

299 Id. at 296.

300 United States v. Booker, 125 S. Ct. 738, 746 (2005).

301 Id. at 738 ,

302 See generally id.

303 Id. at 742 (the court noted that the sentence imposed by the judge was 10 years longer than the range supported by the verdict alone).

304 See 18 U.S.C.A. $\$ 3553$ (b)(1) (West Supp.2004) (this provision allowed the judge to on a caseby-case basis evaluate circumstance that may have not been taken into consideration by the Sentencing Commission and which should result in a different sentence from those described).

305 Booker, 125 S. Ct. at 742.

306 Id.

307 Id. at $744-45$. 
but was rooted in the "ideals [the] constitution assimilated from the common law. ${ }^{308}$

The majority rejected the dissents contention that the Sentencing Guidelines enjoyed a "traditional judicial authority to increase sentences [by] . . . taking [into] account . . . any unusual blameworthiness in the manner employed in committing a crime." ${ }^{, 309}$ The majority responded by noting that "in today's world," tradition did not provide a "sound guide to enforcement of the Sixth Amendment's guarantee of a jury trial.,"310

\section{ANALYSIS}

\section{REVIEWING FLORIDA'S DEATH PENALTY SENTENCING SCHEME IN LIGHT OF APPRENDI, RING, BLAKELY AND BOOKER}

The string of cases reviewed clearly shows that under the Eighth Amendment a state's capital punishment statute must provide guided discretion to a jury or sentencer in determining whether the imposition of death is applicable. ${ }^{311}$ Moreover, under the Fifth and Sixth Amendments, a jury must consider aggravating circumstances, other than that the defendant was previously convicted, in order to result in the imposition of the maximum punishment authorized by the verdict. ${ }^{312}$

The United States Supreme Court has interpreted the statutory maximum, including the imposition of death, as the maximum a defendant is exposed to by virtue of the jury's verdict irrespective of whether the maximum is attached to the actual crime being charged or a separate statute which enhances the punishment. ${ }^{313}$ Apprendi, Ring, and more recently Blakely and Booker clearly indicate the position the United States Supreme Court has taken with regard to the imposition of sentences that are not solely determined by a jury. This Comment's position that Florida's death penalty sentencing scheme is unconstitutional is dependent on several primary propositions.

308 Id. at 753 (the Court emphasized that the Framers feared the threat of "judicial despotism" which could occur absent a jury from "arbitrary punishments upon arbitrary convictions").

309 Id. at 751.

310 Id.

311 Furman, 408 U.S. 238.

312 Id.; Apprendi, 530 U.S. 466; Ring, 536 U.S. 584; Blakely, 542 U.S. 296 (These amendments are applicable to the states through the Fourteenth Amendment.)

313 See Ring, 536 U.S. 589-602 (outlining the meaning of statutory maximum, "[a] defendant may not be "exposed to a penalty exceeding the maximum he would receive if punished according to the facts reflected in the jury verdict alone ... [ $\mathrm{t}$ ] his prescription governs. . . even if the State characterizes the additional findings made by the judge as "sentencing factors"); the Court further addressed whether this definition applied to capital defendants, "Capital defendants, no less than noncapital defendants . . . are entitled to a jury determination of any fact on which the legislature conditions an increase in their maximum punishment"). Id at 589 . 
First, the role of the jury in Florida's sentencing scheme is merely advisory and not determinative. ${ }^{314}$ Second, under Florida's sentencing structure the maximum sentence a judge may impose on a defendant convicted of capital murder, solely on the jury's verdict, is life imprisonment, and not death. $^{315}$ Third, the guidelines placed in the statute such as the weighing of aggravating and mitigating factors in the death penalty sentencing phase is mandatory under the mandates of Furman. ${ }^{316}$ Fourth, the mere presence of aggravating factors in and of themselves is not outcome determinative as to the imposition of death. ${ }^{317}$ And fifth, it is the outcome of the balancing of opposing factors, aggravating against mitigating, which ultimately determines whether or not the death penalty is appropriate; ${ }^{318}$ a role which the jury and not the judge should be carrying out.

\section{THE “TRUE” ROLE OF THE JURY}

Florida's Supreme Court continues to hold that its death penalty sentencing scheme is constitutionally valid. ${ }^{320}$ In Bottoson v. Moore, Florida's Supreme Court had an opportunity to address the implications of Apprendi and Ring on Florida's capital sentencing scheme. ${ }^{321}$ Linroy Bottoson was convicted for first-degree murder and in accordance with the jury's recommendation, the trial judge sentenced appellant to death. ${ }^{322}$ During the sentencing phase, the judge imposed the death sentence after determining the presence of the following aggravating circumstances: petitioner had previously been convicted of a violent crime; the murder was committed during the commission of a felony and for the purpose of avoiding arrest; and that the murder was "especially heinous, atrocious, or cruel.",323 The trial judge found no mitigating circumstances. ${ }^{324}$

While Bottoson was unsuccessful in his appeals to Florida's Supreme Court under a writ of habeas corpus, the United States Supreme Court postponed his execution while it decided Ring. ${ }^{325}$ On June 28, 2002, after decid-

314 See supra note 95 , (the jury shall deliberate and render an advisory sentence to the court).

315 Fla. STAT. $\$ 921.141$ (3) (West 2003).

316 Furman, 408 U.S. 238.

317 FLA. STAT. § 921.141 (3) (West 2003).

318 Id.

319 See Apprendi, 530 U.S. 466 (holding that statutory maximum is the maximum a judge may impose without additional findings). See also Ring, 536 U.S. 584 (the Court applied Apprendi to capital sentencing scheme); Booker, 125 S. Ct. 738 (holding that additional facts a judged found under a sentencing scheme which was mandatory and restricted judicial discretion when imposing sentences violates the Sixth Amendment).

320 Bottoson, 833 So. 2 d 693 (Fla. 2002). See Hilliker, supra note 167, at 432.

321 Bottoson, 833 So. 2d 693 (Fla. 2002).

322 Bottoson v. State, 443 So.2d 962, 963 (Fla. 1983).

323 Id. at 967.

324 Id.

325 Bottoson, 833 So. 2 d at 695. 
ing Ring, the United States Supreme Court denied certiorari in Bottoson's case, which in turn ended the stay on his execution. ${ }^{326}$ The Florida Supreme Court interpreted the United States Supreme Court's denial of certiorari as indicating that Florida's death penalty statute was constitutional and consistent with Ring. ${ }^{327}$ Although, the United States Supreme Court declined to hear the Bottoson case, the Florida Supreme Court was incorrect when they summarily perceived this to mean that Florida's death penalty was constitutional irrespective of Ring since it is "well-settled . . . that denial of certiorari imparts no implication or inference concerning the court's view of the merits., ${ }^{328}$

Furthermore, Justice Wells noted that if the Ring case had somehow compromised the constitutionality of Florida's death penalty statute, the Supreme Court would likely not have removed the stay knowing that the petitioner would be executed. Instead, the Court would have remanded the case for further consideration. What neither Justice Wells or the U.S. Supreme Court considered, however, was whether rule in Ring could apply retroactively to criminal cases on final or direct appeal.

On June 24, 2004, the United States Supreme Court held that the rule in Ring did not apply retroactively to death penalty cases already on final or direct review. ${ }^{329}$ The Court in Summerlin held that the Ring decision merely altered the method of determining the presence of facts not changing the facts themselves. ${ }^{330}$

As further justification for upholding Florida's capital sentencing scheme, the Florida Supreme Court pointed out that Florida's death penalty statute had been thoroughly scrutinized and held to be constitutional by the United States Supreme Court over the past twenty-six years. ${ }^{331}$ One such case used to support the court's position was Hildwin v. Florida. ${ }^{332}$ However, the Hildwin case was one of the cases utilized by the Supreme Court in Walton v. Arizona to uphold the now unconstitutional Arizona statute in which a judge was permitted to determine sentencing factors without the assistance of a jury. ${ }^{333}$ While the Supreme Court later overruled Walton

$326 I d$. at 697.

327 Id. at 698 (Wells, J. concurring).

328 Hathorn v. Lovorn, 457 U.S. 255, 262 n.11 (1982); see also Singleton v. C.I.R., 439 U.S. 940, 944 (1978) (holding that the "Court has rigorously insisted that . . . a denial [of certiorari] carries with it no implication whatever regarding the Court's views on the merits of a case which it has declined to review.").

329 Schriro v. Summerlin, 124 S. Ct. 2519 (2004) (holding that the Ring decision did not apply retroactively to death penalty cases already on final review because the Ring decision was procedural and not substantive).

$330 I d$. at 2524.

331 Bottoson, 833 So. $2 \mathrm{~d}$ at 697.

332 Id. at 695 n. 4 .

333 Walton, 497 U.S. 639. 
with Ring, the Florida Supreme Court continues to distinguish Florida's sentencing scheme from that which was used in Arizona. ${ }^{334}$

The Florida Supreme Court holds to the distinction that while Arizona's statute permitted a judge to determine the presence of aggravating and mitigating circumstances without a jury, under Florida's statute, a judge does not sit alone. ${ }^{335}$ A judge and a jury hear the evidence and then based on the advisory sentence of the jury, the judge decides whether the imposition of death is warranted. ${ }^{336}$ The distinction of this jury-involvement procedure that the court points to is weak seeing as the United States Supreme Court has held that " $[\mathrm{t}]$ he dispositive question . . . is one not of form, but of effect." ${ }^{, 337}$ The jury's true effect in Florida under its capital sentencing scheme was clear to the United States Supreme Court when it held that,

[a] Florida trial court no more has the assistance of a jury's findings of fact with respect to sentencing issues than does a trial judge in Arizona because in Florida[,] the jury recommends a sentence, but it does not make specific factual findings with regard to the existence of mitigating or aggravating circumstances and its recommendation is not binding on the trial judge. ${ }^{338}$

Is there a difference between Florida's jury advisory sentence and Arizona's judge who sits alone? Perhaps in form there is, yet in substance is there a distinction? A clarification of the jury's role in Florida's scheme is needed to truly determine whether there is a difference.

After a defendant is found guilty of capital murder, a separate proceeding is commenced. ${ }^{339}$ During this sentencing phase, the prosecution and the defense introduce aggravating and mitigating evidence before a judge and jury. ${ }^{340}$ At the conclusion, the jury must weigh the factors and by a majority render an advisory sentence to the judge. ${ }^{341}$ This advisory opinion is not binding on the court for the court must independently weigh the circumstances and enter its own decision. $^{342}$ Under existing Florida law, a judge

\footnotetext{
334 Bottoson, 833 So. 2d at 699 (Quince, J. concurring) (the United States Supreme Court receded Walton because the Arizona statute allowed "a sentencing judge, sitting without a jury, to find an aggravating circumstances necessary for the imposition of death penalty[;] [t]his language alone distinguishes the Florida death scheme from Arizona['s]").

335 Id.

336 Bottoson, 833 So. $2 \mathrm{~d}$ at 700.

337 Ring v. Arizona, 536 U.S. 584, 602 (2002).

338 Walton, 497 U.S. 648. See also Bottoson, 833 So. 2 d at 704 (Anstead, C.J., concurring in result only) (noting that Florida's Supreme Court cannot ignore the impact of Ring and the Supreme Court's comparison of Arizona's and Florida's death penalty schemes).

339 FLA. STAT. § 921.141(1) (2002).

340 Id.

341 Fla. STAT. § 921.141(2) (2002).

342 FLA. STAT. $\$ 921.141(3)$ (2002). However, the trial judge must accord deference to the jury's recommendation. See Tedder v. State, 322 So. 2d 908, 910 (Fla. 1975).
} 
may find aggravating circumstances, during a post-sentencing hearing, that were never offered before a jury. ${ }^{343}$ Furthermore, if a death sentence is imposed, it is the judge's findings of fact that are reduced to writing, not the jury's. ${ }^{344}$ Without the jury's written records of findings, an appellate court would not be able to review what, if any factors a jury found to be present during the sentencing phase. Therefore, the extent of the jury's role in the sentencing phase becomes unclear, because during a post-conviction appeal, the appellate court cannot give adequate consideration to a jury's recommended sentence, since it is the judge's finding of facts which are reviewed. ${ }^{345}$

Additionally, it appears as if the role of the jury is at times not as vital as the Florida Supreme Court in Bottoson claimed it to be. ${ }^{346}$ In Sochor v. Florida, the United States Supreme Court reversed an affirmed decision by the Florida Supreme Court where the petitioner argued that his Eighth Amendment right against cruel and unusual punishment was violated when during the sentencing phase the jury weighed an aggravating factor that was not enumerated in Florida's Statue. ${ }^{347}$ The Florida Supreme Court held the error to be harmless and affirmed the trial courts holding. ${ }^{348}$ The petitioner appealed to the United States Supreme Court and although the court vacated and remanded, Florida argued before the Court that the error was harmless because after all, the trial judge is the sentencer, and the jury merely functions in an advisory capacity.

While only three states use a "hybrid" sentencing system, ${ }^{350}$ only Delaware requires a unanimous decision when determining the presence of

343 Davis v. State, 703 So. 2d 1055, 1061 (Fla. 1998).

344 Fla. STAT. § 921.141(3)(a)(b) (2002).

345 Bottoson, 833 So. 2d at 724 (Pariente, J. concurring in result only) (observing that in Washington v. State, 835 So. 2d 1083 (Fla. 2002), where the trial judge overrode a jury's recommendation for life sentence and on appeal at that time, the court could evaluate the jury's consideration of the aggravating and mitigating circumstances). See also id. at 708 (Anstead, C.J. concurring in result only) (noting that a potential Furman problem arises because the jury's recommendation is not supported by findings of fact and thus a reviewing court will not be able to accurately determine what factors the jury found when making its recommendation).

346 See generally Bottoson, 833 So. 2 d 693 (Fla. 2002).

347 Sochor v. Florida, 504 U.S. 527, 532 (1992).

348 Sochor v. State, 580 So.2d 595, 604 (1991).

349 See Sochor, 504 U.S. 527 (respondent's brief 1992 WL 606715 (U.S.) (Under Florida's sentencing scheme, the jury's role is strictly advisory. The trial judge makes independent factual findings, in writing, to support a sentence of death).

350 These states are Florida, Alabama and Delaware. See Aarons, supra note 86, at 18; Gregg v. Georgia, 428 U.S. at 187, 198 (1976) (noting that Georgia's new sentencing scheme required that a jury make specific findings of facts as to the presence of aggravating and or mitigating circumstances before the imposition of death); Proffitt v. Florida, 428 U.S. 242, 248-49 (1976) (the basic difference between the Florida system and the Georgia system is that in Florida the trial judge determines the sentence rather than the jury; the Florida procedures for imposition of the death penalty satisfy the constitutional deficiencies identified in Furman). 
aggravating and or mitigating factors. ${ }^{351}$ Florida does not require a unanimous decision when deciding the presence of aggravating or mitigating factors. ${ }^{352}$ Justice Anstead, concurring in result only in Bottoson argued that Apprendi and Ring mandated that "aggravating sentencing factors, just like elements of a crime, must be found by a unanimous jury vote." ${ }^{, 353}$ Although not available to the majority in Bottoson, the United States Supreme Court in Blakely held that, "[t]he Framers would not have thought it too much to demand that, before depriving a man of . . . his liberty, the State should suffer the modest inconvenience of submitting its accusation to the unanimous suffrage of twelve of his equals and neighbors ... rather than a lone employee of the State." ${ }^{354}$ In Blakely the Court further noted that whereas suffrage provides a balance in favor of the people over elected officials in the legislative and executive branches, a right to a jury trial allows this control over the judiciary. ${ }^{355}$

\section{STATUTORY MAXIMUM SENTENCE}

Apprendi mandated that any fact, not including a prior conviction, which increases the penalty beyond the statutory maximum, must be submitted to a jury. ${ }^{356}$ Ring expanded the application of Apprendi to encompass capital punishment statutes. ${ }^{357}$ The Florida Supreme Court in Bottoson held that the traditional definition of maximum statutory sentence is "that sentence which a state legislature or Congress has determined to be the outer limit of what can be imposed for a particular crime." ${ }^{, 358}$ As applied to Florida, this would translate that upon conviction of a capital felony, death would be the maximum statutory sentence. ${ }^{359}$ Yet, mandatory death penalty statutes that expose a defendant to death solely based on the trial jury's verdict are unconstitutional. ${ }^{360}$ Recall that in Dobbert, the United States Court

\footnotetext{
351 See Del. Code ANN. tit. 11, §4209(3)(b)(1) (stating that "in order to find the existence of a statutory aggravating circumstance as enumerated in subsection (e). . beyond a reasonable doubt the jury must be unanimous as to the existence of that statutory aggravating circumstance). However the jury's decision is not binding on the judge. Ortiz v. State, 869 A. 2d 285, 309-10 (Del. 2005).

352 Proffitt, 428 U.S. at 248-49; FLA. STAT. § 921.141 (2).

353 Bottoson v. Moore, 833 So. 2d 693, 709 (Fla. 2002) (Anstead, J. concurring).

354 Blakely v. Washington, 124 S. Ct. 2531, 2543 (2004).

$355 I d$. at 2538 .

356 See Apprendi v. New Jersey, 530 U.S. 466, 490 (2000) (holding that "any fact that increases the penalty for a crime beyond the prescribed statutory maximum must be submitted to a jury . . . and established beyond a reasonable doubt.").

357 See Ring v. Arizona, 536 U.S. 584, 609 (2002) (holding that Walton and Apprendi were irreconcilable and Sixth Amendment jurisprudence required that aggravating circumstance necessary for imposition of the death penalty be found by a jury).

358 Bottoson, 833 So. $2 \mathrm{~d}$ at 700.

359 Id. at $700 \mathrm{n} .10$.

360 See Woodson v. North Carolina, 428 U.S. 280, 304-05 (1976) (finding that mandatory death penalty statutes are unconstitutional because they fall short of allowing the sentencer to consider relevant aspects of the character a convicted defendant before the imposition of a sentence of death).
} 
held that being sentenced to death in Florida was "not automatic." this reason, the mandates of Furman and Woodson require the states to conduct a separate proceeding to determine whether the imposition of death is appropriate. $^{362}$ It is during this separate procedure under Florida's death penalty sentencing scheme that the defendant is in fact exposed to the possibility of being sentenced to death. ${ }^{363}$ In Ring, Arizona argued that the statutory maximum penalty for first-degree murder was death. ${ }^{364}$ However, the Court held that Arizona's first-degree murder statute cross-referenced a separate sentencing section which directed the judge to "conduct a separate sentencing hearing to determine the existence or nonexistence of certain circumstances before imposing the sentence." 365 If Florida's sentencing structure parallels Arizona's statute in design, in that the trial jury's verdict alone will not be sufficient to impose the penalty of death on the defendant, then Florida's sentencing scheme is bound by the rules developed in Apprendi and Ring. Although the definition of "statutory maximum" may be difficult to discern, the Court in Blakely provided guidance. ${ }^{366}$ Blakely explained that a statutory maximum, under an Apprendi application, was the maximum sentence a judge could impose "solely on the basis of the facts reflected in the jury verdict or admitted by the defendant."367 The Blakely Court went on to hold that a judge, who imposes a sentence beyond the jury's verdict, has exceeded his authority. ${ }^{368}$ Despite the precedent, the Florida Supreme Court continues to find the death penalty statute constitutional. $^{369}$

\section{WEIGHING OF THE FACTORS: MANDATORY GUIDELINES}

A court must follow Florida's death penalty scheme when determining whether an individual should be sentenced to death or life imprisonment. ${ }^{370}$

361 Dobbert, 432 U.S. 282.

362 Furman v. Georgia, 408 U.S. 238, 267 (1972). See Diamond, supra note, 21; Woodson, 428 U.S. at 304 (noting that the "Eighth Amendment requires consideration of the character and record of the individual defendant.").

363 FLA. STAT. § $921.141(2)$.

364 Ring v. Arizona, 536 U.S. 584, 592 (2002).

365 Id. ("Arizona['s] first-degree murder statute [resembling Florida's murder statute], authorize[d] a maximum penalty of death only in a formal sense, for it explicitly cross-references the statutory provision requiring the finding of an aggravating circumstance before imposition of the death penalty.").

366 Blakely v. Washington, 124 S. Ct. 2531, 2537 (2004).

367 Id. at 2537.

368 Id.

369 See State v. Duncan, 894 So. 2d 817, 831 (Fla. 2004); Power v. State, 886 So. 2d 952, 965 (Fla. 2004).

370 FLA. STAT. $\$ 941.141(1)$ (stating that, "the court shall conduct a separate sentencing proceeding ...") (emphasis added). 
The trial court's verdict alone does not sentence an individual to death. ${ }^{371}$ It is the legislatively created mandate, separate from the statute prescribing the offense, which ultimately exposes a defendant to death. The United States Supreme Court, through its capital punishment jurisprudence, has held that the determination to impose the death penalty on a given individual must be provided by a sentencer who is governed by a procedure which furnishes guidance in determining the ultimate sentence. ${ }^{372}$ Although the United States Supreme Court's recent decisions in Booker v. United States dealt with federal sentencing guidelines, implications to Florida's death penalty guidelines may be inferred. ${ }^{373}$

Relying on Apprendi and Blakely, the Court in Booker held that the Sixth Amendment right to trial by jury applied to mandatory sentencing schemes and therefore, relevant facts required to impose a sentence must be determined by juries, not judges. ${ }^{374}$ The Federal Guidelines bound the sentencing court in Booker; the judge was mandated to follow the provisions. ${ }^{375}$ The Court concluded that because these guidelines were mandatory, they had the force and effect of laws. ${ }^{376}$ As was the sentencing court in Booker, the sentencing court in Florida is bound by the hybrid-sentencing scheme where the weighing of factors determines the sentence to be imposed. ${ }^{377}$ The Court in Booker distinguished the mandatory guidelines from advisory provisions holding that, "[i]f the Guidelines . . . could be read as merely advisory provisions that recommended, rather than required . . . their use would not implicate the Sixth Amendment; [however, the] "Guidelines as written . . . are not advisory; they are mandatory and binding on all judges . ...”378 Through Booker, the Court extends the protection of the Sixth Amendment to mandatory sentencing schemes noting that these principles "are not the product of recent innovations in our jurisprudence, but rather

\footnotetext{
371 Id. ("Upon conviction . . o of guilt . . of a capital felony . . the court shall . . .) (emphasis added).

372 See generally, Gregg v. Georgia, 428 U.S. 153, 195 (1976).

373 See Behl v. Florida, 898 So. 2d 217, 221 (Fla. App 2 Dist 2005) (holding that the points assessed in the sentencing phase were not based on a determination made by the jury, and thus under a presumptive sentencing structure where judges are given a narrow range of permissible sentences, Booker mandates that a judge cannot find facts beyond those found by the jury).

374 United States v. Booker, 125 S. Ct 738, 742 (2005).

375 Id.

376 Id. at 749-50 (citing Mistretta v. United States, 488 U.S. 361, 367 (1989) (noting that Congress chose to "adopt a "mandatory-guideline system" rather than a system that would have been "only advisory," and that the statute "makes the Sentencing Commission's guidelines binding on the courts).

377 See FLA. STAT. $\$ 921.141$ (2). While the capital punishment sentencing scheme statue in Florida is not entirely analogous to the Federal Sentencing Guidelines, it is binding on the courts and its origin can be traced to the Furman decision which recognized that a death penalty scheme that does not provide the sentencing body with statutorily guided discretion violates the Eighth Amendment. See also Madia, supra note 69, at 87 (noting that a separate sentencing phase is required under Furman and that such a process "provides an individualized consideration of the defendant ....").

378 Booker, 125 S. Ct. at 749-50.
} 
have their genesis in the ideals our constitutional tradition assimilated from the common law." ${ }^{379}$ One may try to distinguish Florida's capital sentencing scheme from the Guidelines discussed in Booker; however, they share a common theme, both are mandatory. ${ }^{380}$ Furthermore, other factors add to the compulsory character of the state's capital punishment sentencing scheme. Its creation was based on the establishment that "the death sentence is unique in its severity and its irrevocability.", Also, "the jury-trial guarantee of the Sixth Amendment is that all facts essential to imposition of the level of punishment that the defendant receives--whether the statute calls them elements of the offense, sentencing factors, or Mary Jane--must be found by the jury beyond a reasonable doubt. ${ }^{, 32}$ The state's capital punishment sentencing scheme does not appear to provide advisory provisions that merely recommend sentencing ranges. After all, the language is quite clear: "[T]he court, after weighing the aggravating and mitigating circumstances, shall enter a sentence of life or death ...." (emphasis added). ${ }^{383}$

In both Duncan and Power, the Florida Supreme Court utilized the trial court's verdict during the guilt phase to avoid a Ring violation. ${ }^{384}$ The sentencing court carried over the trial court jury's findings of fact during the guilt/innocence phase as aggravating factors in order to comply with both the principles in Ring and Florida's capital punishment sentencing scheme. The court's rationale was that the aggravating factors needed to satisfy the imposition of death pursuant to the penalty phase were "charged by indictment and found unanimously by the jury.",385 On the surface, this strategy seems to comport with the holdings in Apprendi and Ring. ${ }^{386}$

However, the court overlooks the underlying purpose of Florida's capital punishment sentencing scheme. Furman and its progeny have held that in order for a capital sentencing scheme to be constitutional, the statute must "genuinely narrow the class of persons eligible for the death penalty . . . and must justify the imposition of a more severe sentence on the defendant

379 Id. at 753.

380 See id. at 749-750. The court is bound to weigh the factors and decide between a sentence of life imprisonment or death. See also McClesky v. Kemp, 481 U.S. 279, 313 (1987) (comparing the sentencing guidelines to "Gregg-type statute[s]"-referring to Gregg v. Georgia, 428 U.S. 187, 153 (1976)).

381 Gregg, 428 U.S. 187.

382 Ring v. Arizona, 536 U.S. 584, 610 (2002).

383 FLA. STAT. § 941.141(3).

384 State v. Duncan, 894 So. 2d 817, 831 (Fla. 2004) (holding that because an aggravating factor, prior conviction of a felony, was charged in the indictment and found beyond a reasonable doubt the imposition of the death penalty was constitutional); Power v. State, 886 So. 2d 952, 965 (Fla. 2004) (holding that since the trail court had found that the murder was committed in the commission of various other felonies and found beyond a reasonable doubt Ring and Apprendi were inapplicable).

385 Power, 886 So. 2d at 965.

386 See Apprendi v. New Jersey, 536 U.S. 466, 482 (2000) and Ring, 536 U.S. at 609 (both cases holding other than the fact of a prior conviction any fact that increases the penalty beyond the prescribed statutory maximum must be submitted to a jury and proven beyond a reasonable doubt). 
compared to others found guilty of murder." ${ }^{387}$ Unlike any other area, when dealing with capital punishment, the Court has placed special constraints on states' "legislatures' ability to determine what facts shall lead to . . . punishment[, and] ... [the] ability to define crimes. ${ }^{388}$ Aggravating factors are designed to guide the sentencer with a "rational criteria [which] . . . [will] narrow [his] . . . judgment as to whether the circumstances of a particular defendant's case meet the [constitutional] threshold." 389 By allowing the trial court's factual findings to survive any Ring infirmity, the Florida Supreme Court does not consider that the sentencing statute calls for the weighing of the aggravating and mitigating factors, not the mere existence of an aggravating factor. ${ }^{390}$ The outcome of weighing the opposing factors is the process by which the sentence is ultimately determined. For if the court relies solely on presence of the aggravating factors, the court is either doing the actual weighing or the trial jury's finding of fact is not being considered in light of any mitigating factors within the context of sentencing. Mitigating factors are an intricate part of the statute's weighing process in as much as, "mitigating factors ... might induce a sentencer to give a lesser punishment." "391 Furthermore, if the findings of fact which established the presence of aggravating factors are permitted to be "imported" from the guilt phase and used in the sentencing phase, other than providing a nonbinding advisory opinion, what role does the sentencing jury play? The responsibility of the sentencing jury must be genuine because "it is constitutionally impermissible to rest the death sentence on a determination made by a sentencer [that] has been led to believe that the responsibility for determining the appropriateness of the defendant's death rests elsewhere." ${ }^{392}$

\section{CONCLUSION}

The Furman Court understood that to allow the trial jury to sentence the defendant to death based solely on the findings of fact that it had considered to establish his guilt would not take into consideration "particularized consideration of relevant aspects of the character and record of each convicted defendant before the imposition upon him of a sentence of death." ${ }^{393}$ Therefore, it is in this subsequent proceeding that the aggravating circumstances must be weighed against mitigating circumstances to estab-

387 Zant v. Stephens, 462 U.S. 862, 877 (1983).

388 Apprendi, 536 U.S. at 522-23 (Thomas, J., concurring).

389 McClesky v. Kemp, 481 U.S. 279, 306 (1987).

390 FLA. STAT. $\S \S 921.141$ (2)(a), (3). (it is not the mere existence of aggravating factors, but rather the non-existence of any outweighing mitigating circumstances that renders the imposition of the death penalty appropriate).

391 Ring, 536 U.S. at 611.

392 Caldwell v. Mississippi, 472 U.S. 320, 328-29 (1985).

393 Woodson v. North Carolina, 428 U.S. 280, 303 (1976). 
lish the "nature and circumstances of the offense and the history and characteristics of the defendant.",394

It is the result or conclusion of the process by which the statutory factors are weighed that truly imposes the appropriate sentence. Merely because elements of a crime, which are required to be proven beyond a reasonable doubt by a jury during the guilt phase, overlap aggravating factors that need to be weighed against mitigating factors, does not cure the state's constitutional infirmity. The facts determined at the trial level serve their purpose within the trial level context in which they are established-to prove that a crime was committed and to establish the defendant's guilt or innocence. $^{395}$

In cases where facts used to establish guilt overlap facts needed to determine the presence of aggravating factors, the jury's trial findings of fact should not be used in the context of the sentencing phase. While the need to have the facts proven beyond a reasonable doubt at the sentencing phase may not be constitutionally required, at a minimum, these facts must be weighed against mitigating factors to determine the proper sentence. In the sentencing phase framework, the findings which ultimately determine the proper punishment must be determined by a sentencing jury and not a judge, for "the jury [can]not function as circuitbreaker in the State's machinery of justice if it were relegated to making a determination that the defendant [committed the murder] . . . a mere preliminary to a judicial inquisition into the facts of the crime the State actually seeks to punish. ${ }^{396}$ In essence, Florida does not seek to impose a sentence of death on all who commit murder, not even those who commit murder when aggravating circumstances are established. The death penalty is sought only on those who, after considerations insufficient mitigating circumstances exist which outweigh the aggravating circumstances.

During a capital murder case, the jury convicts the defendant of murder when it determines that a crime has been committed and the defendant is responsible. This determination of guilt alone, without any additional findings, does not permit the judge to impose death. ${ }^{397}$ However, as in Booker, a second proceeding is held to determine the appropriate sentence. To reach the appropriate sentence, aggravating factors must be weighed against mitigating factors. It is the result of this "balancing" of factors that ultimately determines the sentence. Just as the judge in Booker found that the defendant possessed 566 grams of crack in excess to the trial jury's

394 United States v. Booker, 125 S. Ct 738, 743 (2005).

395 The findings of the trial jury, although relevant to the guilt or innocence of the charged crime, do not take into account the relevant aspects of the character of the defendant or fully consider and give effect to the mitigating evidence which Furman mandated.

396 Blakely v. Washington, 124 S.Ct. 2531, 2539 (2004).

397 FLA. STAT. § 941.141(1). 
findings, ${ }^{398}$ in Florida, the sentencing judge alone, in excess to the trial jury's finding of guilt, renders the outcome of the "balancing" of the aggravating and mitigating factors. ${ }^{399}$ In the final analysis, this judicial determination exceeds the sentence which may be imposed solely on the basis of the facts reflected by the jury verdict.

Consequently, as the Court held in Blakely, "the jury's verdict alone does not authorize the sentence. The judge acquires that authority only upon finding some additional fact." ${ }^{, 400}$ Since the Florida judge acquires the authority to impose the sentence of death pursuant to the capital sentencing scheme, and not the trial court's verdict, the actual outcome of the weighing of the factors is a finding of fact that ultimately determines the proper sentence. In sum, "[t]here is no relevant distinction between the sentence imposed pursuant to the Washington statutes in Blakely, . . . the sentences imposed pursuant to the Federal Sentencing Guidelines [in Booker], . . . and the death penalty in Florida."

Florida's capital sentencing scheme came about from its compliance with Furman; however, "the prohibition of the Eighth Amendment relates to the character of the punishment, and not to the process by which it is imposed." ${ }^{402}$ Florida's process, while conforming to Furman, does not conform to the United State Supreme Court's recent jurisprudence regarding the principles behind the jury trial right. Florida can remedy this deficiency by amending the statute and allow a jury, and not the judge, to determine the proper sentence. After all:

jurors possess an important comparative advantage over judges, ... . they are more attuned to the community's moral sensibility," . . . because they "reflect more accurately the composition and experiences of the community as a whole. Hence they are more likely to "express the conscience of the community on the ultimate question of life or death," and better able to determine in the particular case the need for retribution, namely, "an expression of the community's belief that certain crimes are themselves so grievous an affront to humanity that the only adequate response may be the penalty of death. ${ }^{403}$

398 Booker, $125 \mathrm{~S} . \mathrm{Ct}$ at 742

399 FLA. STAT. § 941.141(3).

400 Blakely, 124 S.Ct. at 2538.

401 Booker, $125 \mathrm{~S} . \mathrm{Ct}$ at 743.

402 Ring v. Arizona, 536 U.S. 584, 610 (2002) (Scalia, J., concurring).

403 Id. at 615 (Breyer, J. concurring) (citing Justice Stevens in his long held stance that a jury is the proper decision maker when the imposition of death is at issue.) 